\title{
A landscape-oriented approach to urbanisation and early state formation on the Konya and Karaman plains, Turkey
}

\author{
Michele Massa, ${ }^{1}$ Christoph Bachhuber, ${ }^{2}$ Fatma Şahin, ${ }^{3}$ Hüseyin Erpehlivan, ${ }^{4}$ \\ James Osborne ${ }^{5}$ and Anthony J. Lauricella ${ }^{5}$ \\ ${ }^{1}$ British Institute at Ankara, UK, ${ }^{2}$ University of Oxford, UK, ${ }^{3}$ Çukurova University, Turkey, \\ ${ }^{4}$ Bilecik University, Turkey, and ${ }^{5}$ University of Chicago, USA \\ m.massa@ucl.ac.uk
}

\begin{abstract}
This paper synthesises the data and results of the Konya Regional Archaeological Survey Project (2016-2020) in order to address the earliest evidence for cities and states on the Konya and Karaman plains, central Turkey. A nested and integrative approach is developed that draws on a wide range of spatially extensive datasets to outline meaningful trends in settlement, water management and regional defensive systems during the Bronze and Iron Ages. The significance of the regional centre of Türkmen-Karahöyük for a reconstruction of early state polities between the 13th and eighth centuries BCE is addressed. In light of this regional analysis, it is tentatively suggested that, during the Late Bronze Age, Türkmen-Karahöyük was the location of the city of Tarhuntašša, briefly the Hittite capital during the reign of Muwatalli II. More assuredly, based on the analysis of the newly discovered Middle Iron Age TÜRKMENKARAHÖYÜK 1 inscription, it is proposed that Türkmen-Karahöyük was the seat of a kingdom during the eighth century BCE that likely encompassed the Konya and Karaman plains.
\end{abstract}

\section{Özet}

Bu makale Konya Bölgesi Arkeolojik Yüzey Araştırması Projesi’nin (2016-2020) verilerini ve sonuçlarını Orta Anadolu'da Konya ve Karaman ovalarındaki en erken şehirlere ve eyaletlere dair kanıtların saptanması amacıyla sentezlemektedir. Tunç Çă̆ı ve Demir Çağı'ndaki yerleşim, su kaynaklarının yönetimi ve bölgesel savunma sistemlerine dair eğilimleri ortaya koymak için çok çeşitli mekansal veri setlerinden yararlanan, iç içe ve bütünleştirici bir yaklaşım geliştirilmiştir. M.Ö. 13. ve sekizinci yüzyıllar arasındaki erken devlet rejimlerinin anlaşılabilmesi için bölgesel bir merkez olan Türkmen-Karahöyük’ün önemi ele alınmıştır. Bu bölgesel analizler ışı̆̆ında Türkmen-Karahöyük'ün, Geç Tunç Çağı'nda, II. Muwatalli'nin hükümranlığı sırasında Hitit başkenti olan Tarḩuntašša olarak konumlandırılması önerilebilmektedir. Daha kesin olarak, yeni keşfedilen TÜRKMEN-KARAHÖYÜK 1 Orta Demir Çağı yazıtının analizine dayanarak, Türkmen-Karahöyük'ün M.Ö. sekizinci yüzyılda muhtemelen Konya ve Karaman ovalarını kapsayan bir krallığın merkezi olduğu da ileri sürülmektedir.

S ince at least V. Gordon Childe, analytical assessments of the earliest cities and states in the Middle East and eastern Mediterranean have addressed geographically extensive processes, often described with terms like 'centralisation' (Çevik 2007), 'urbanisation' or 'urbanism' (Ur et al. 2007) and 'state formation' (recently, Legarra Herrero 2016). In Anatolia, these are widely understood as secondary processes influenced by Mesopotamian-origi- nated ideas of governance, administrative technologies and other aspects of elite behaviour (Massa, Palmisano 2018). In this paper, we apply a landscape-oriented approach to understand these phenomena on the Konya and Karaman plains (south-central Turkey) between the Bronze and Iron Ages (ca 3200-300 BCE). The new discovery of a major Late Bronze and Iron Age regional centre at TürkmenKarahöyük (Osborne et al. 2020, this volume) is an oppor- 
tunity to synthesise archaeological, philological and palaeoenvironmental data related to the emergence of the earliest cities and states in this region.

The Konya and Karaman plains, an area with a 10,000year history of farming and one of the most productive agricultural basins in modern Turkey, present an ideal case study to address such developments at a regional scale. From its beginning, archaeological research in the basin has also highlighted the existence of substantial mounded settlements, among the largest settlements in pre- and proto-historic Anatolia (for example Mellaart 1955; 1958; 1963). Yet, despite the numerous survey projects that have extensively recorded Bronze and Iron Age settlements (cf. Massa et al. 2019b for an overview and bibliography), most of the analytical focus has been on the Epipalaeolithic to Early Chalcolithic period (ca $15000-5500 \mathrm{BCE}$ ). This is due in part to research undertaken at the UNESCO World Heritage Site of Çatalhöyük that, since its discovery in the late 1950s, has acted as a kind of vortex for excavationbased resources, expertise and analysis in the region. These include James Mellaart's project at Çatalhöyük, David French's investigations of Neolithic to Chalcolithic Can Hasan, Ian Hodder's return to Çatalhöyük, Trevor Watkins and Douglas Baird's subsequent Epipalaeolithic to Neolithic excavations at Pınarbaşı and the latter's Aceramic Neolithic excavations at Boncuklu. Conversely, there is still no in-depth, stratigraphic, well-documented information available for sites occupied after the 'Çatalhöyük horizon', with the exception of cursory reports from excavations at Konya-Karahöyük (for example Alp 1959; 1972) and Sizma Höyük (Robinson 1927).

A major result of this archaeological disinterest is the lack of even basic chrono-typological studies of material culture (for example pottery, chipped stone); the last was published by Mellaart in 1963. With very few exceptions, survey projects have produced only site gazetteers, and to date there has been no attempt to formulate a synthetic assessment of the third to first millennium BCE. For these reasons, the Bronze and Iron Ages of the Konya-Karaman plains have regularly been overlooked in broad reviews of Anatolian archaeology (for example Sagona, Zimansky 2009; Düring 2011) as well as in regional assessments of urbanisation and state formation (for example Çevik 2007; Özdoğan 2011). Following the Early Chalcolithic period, the region simply disappears from the cognitive map of the later prehistoric and early historic periods of Anatolia.

Consequently, this paper has three primary aims. The first is to present a nested interdisciplinary methodology to integrate the rich archaeological, palaeoenvironmental and epigraphic/philological datasets for the Bronze and Iron Ages of the Konya-Karaman plains, with the hope that this will stimulate similar research elsewhere in Anatolia. The second is to evaluate urbanisation and state formation in the region with survey data, focusing on settlement dynamics, water-management practices and regional defensive systems. The third aim is to assess the importance of Türkmen-Karahöyük within south-central Anatolia during the Bronze and Iron Ages. Here, we put forward the hypothesis that the site of TürkmenKarahöyük might be tentatively identified with the Late Bronze Age capital of Tarhuntašša and, more assuredly, with the capital of a Middle Iron Age kingdom.

Our methodology draws from a suite of techniques that have proven particularly effective in the alluvial landscapes of Iraq, Syria and southeastern Turkey (sensu Wilkinson 2003). This includes the use of GIS and remote sensing to integrate environmental, topographic and climatic factors, highlighting their influence on various sociopolitical dynamics and related issues of movement and defensibility. This approach also assesses survey datasets within a spatial analytical framework at scales beyond those of the individual site, following examples in Turkey (Abay 2011; Düring, Glatz 2015; Koparal et al. 2017; Roosevelt, Luke 2017) and elsewhere (for example Bevan, Conolly 2013; Wilkinson et al. 2016).

This analysis represents one aspect of research carried out by the Konya Regional Archaeological Survey Project (KRASP: cf. Massa et al. 2019a; 2019b; also http://www.krasp.net/en/). The datasets used in the following analysis have been generated from survey fieldwork carried out by KRASP since 2017 in the Çumra and Karatay districts and from reassessment of the long history of research in the region. This includes a re-evaluation of palaeoenvironmental and climatic studies, a reanalysis of legacy materials from early survey projects and a synthesis of published archaeological datasets. Furthermore, in 2019 KRASP launched the TürkmenKarahöyük Intensive Survey Project (TISP), aimed at generating higher-resolution data related to the largest urban settlement in the region; the results from the first season of fieldwork are also included in this analysis.

The paper begins by discussing some of the methodological challenges we have faced in our effort to integrate these varied datasets, in particular our attempts to refine identification, geolocation and dating for a large number of archaeological sites. Next, we characterise the climatic and environmental contexts of the four discrete ecological niches that define the KRASP study area: the alluvial/lacustrine plain, the steppe, the spring-fed piedmont and the highlands. We then identify settlement patterns in these varied ecological niches in order to address several demographic trends, including the emergence and shifts of regional centres, the possible evidence for canal irrigation and the appearance of a regional defensive network. Lastly, each of these assessments supports a period-by-period discussion of centrali- 
sation, urbanisation and state-formation processes at the regional scale. The discussion culminates in the identification of Türkmen-Karahöyük as a major urban centre on the Konya and Karaman plains between ca 1300 and 600 $\mathrm{BCE}$ and an evaluation of its geopolitical role within south-central Anatolia.

\section{Approaches to survey data}

Archaeological surveys are increasingly employed as an effective tool to reconstruct sociopolitical and cultural processes at the regional scale, complementing the more fine-grained but spatially limited data derived from excavations. Particularly in northern Mesopotamia, the last decade has witnessed a proliferation of survey projects that have integrated legacy datasets to create sufficiently large analytical windows to address such issues (for example Menze, Ur 2012; Lawrence et al. 2016). The study area of KRASP is the Konya and Karaman plains, a basin of ca $9,000 \mathrm{~km}^{2}$ that we argue represents a suitable analytical unit to understand the dynamics of urbanisation and state formation in south-central Anatolia.

The study area has been the focus of several previous surveys, including those of James Mellaart, Remzi Arık, David French, Ian Todd, Semih Güneri, Hasan Bahar, Sachihiro Omura, Douglas Baird, Yiğit Erbil, Çiğdem Maner and Emre Şerifoğlu among others (see Massa et al. $2019 \mathrm{~b}$ for an overview and bibliography). Yet, with the notable exception of Bahar's projects (Bahar 1999a; Bahar, Koçak 2004), the results of previous fieldwork have been published only as preliminary survey reports, with little in the way of specific data from individual sites. Different standards in data production, different survey techniques and the lack of published coordinates hinder accurate geolocation of sites. In addition, because there has been no attempt to record known sites systematically prior to KRASP, there is some difficulty in identifying sites that have already been recorded (for example under different site names). Moreover, many of the sites that were detected during extensive surveys up to the 1980s have been damaged by industrialised farming, infrastructural development and looting, to the extent that they can no longer be identified on the ground or in modern satellite imagery (Massa et al. 2019a: 174-75; Bachhuber forthcoming). Arguably, the biggest challenge relates to dating the phases of occupation of individual sites, since very often legacy publications do not include detailed presentations and analyses of pottery. When combined with the general scarcity of published ceramic photographs and drawings, this hampers independent reassessment of site assemblages and the development of a chronological framework that encompasses the entire dataset.

KRASP has responded to these challenges by developing a legacy-based research programme to maximise identification, description, geolocation and dating of sites. Our analytical methodology aimed at creating a comprehensive site catalogue of all previously published data has included:

Creating a site database (in Microsoft Access) which includes information on site coordinates, size, description, periods of occupation and relevant literature;

Identifying archaeological sites through the analysis of modern satellite imagery (Google Earth), 30m-resolution Alos World and ASTER GDEM Digital Elevation Models (DEM) and 1:25,000 cartography; cartography also provides toponyms for many of the most prominent sites;

Geolocating known published sites, through georeferentiation of published maps and coordinates provided in publications;

Identifying correspondences between the locations of published sites and archaeological sites identified through satellite imagery, DEM and cartographic analyses;

Calculating the area of mounded settlements, by combining analyses of DEM and satellite imagery with published literature;

Revisiting sites that KRASP can access (within the survey permit defined by the Çumra and Karatay districts) to provide further details and to assess more accurately the extent of sites in different periods;

Reassessing survey materials collected by Mellaart, French and Todd that are currently stored at the British Institute at Ankara (BIAA; Bachhuber, Massa 2016).

With this methodology, KRASP has assembled a site gazetteer of about 490 sites, which will be drawn upon in the following analysis and which has been integrated with the new datasets generated by KRASP fieldwork (ca 120 sites; see Massa et al. 2019a; 2019b for reports and discussion of methodology). The gazetteer includes sites from the Konya province (districts of Derbent, Ilgın, Kadınhanı, Sarayönü, Selçuklu, Meram, Akören, Bozkır, Çumra, Güneysınır, Karatay, Karapınar) and the Karaman province (districts of Kazımkarabekir, Karaman Merkez, Ayrancı) (fig. 1). Despite our collation of legacy data we have encountered several constraints at sites not yet visited by KRASP that are linked to how the data were originally generated in the field and to issues of archaeological visibility/recovery of dateable materials.

The first major limitation is that earlier surveys generally focused on mounded formations (höyüks/tells) on the plains, often neglecting other site types beyond the alluvial plains (Massa et al. 2019a: 163-64) and/or evidence for habitation that did not produce easily detectable accumulations of archaeological deposits. This 


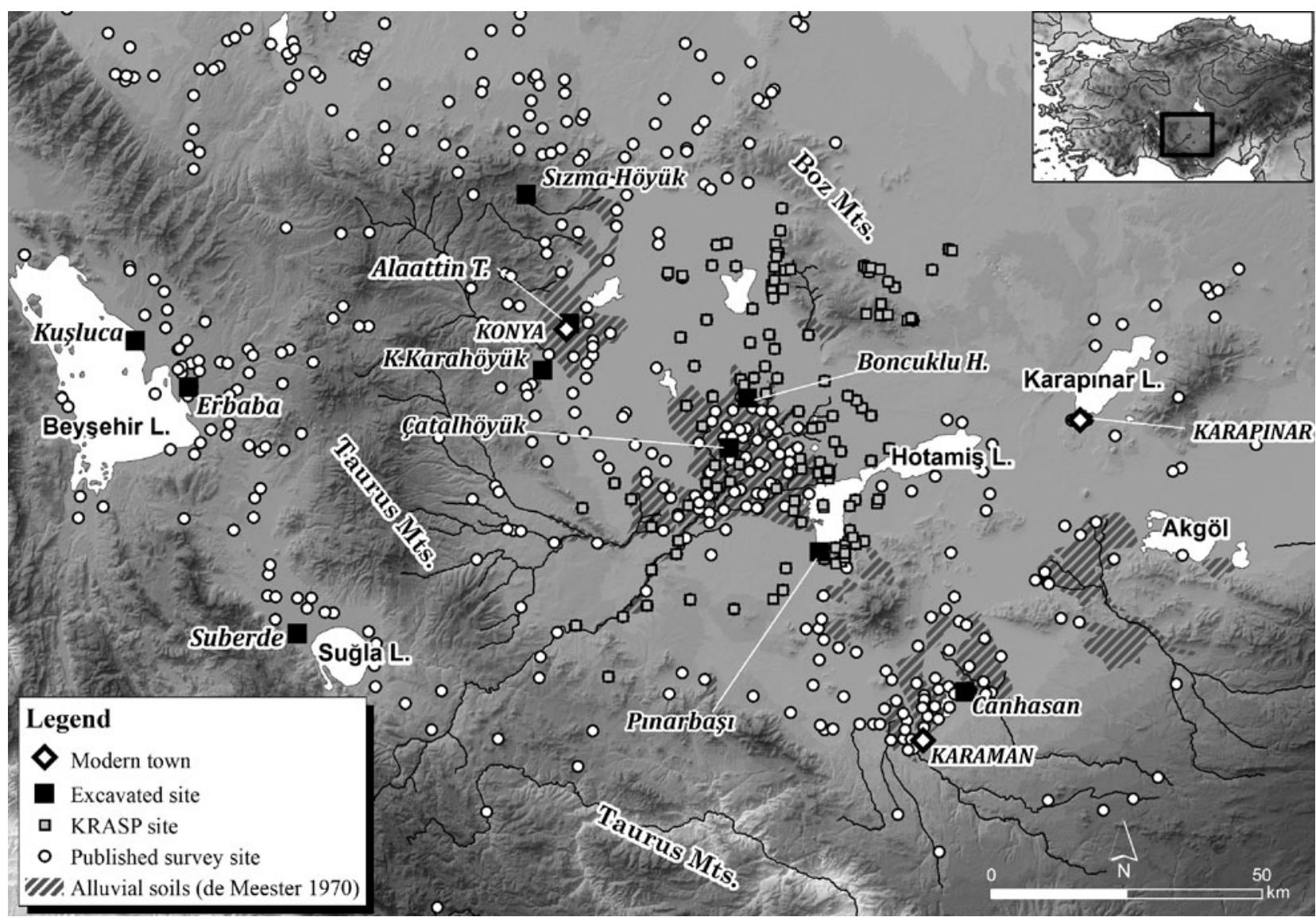

Fig. 1. Map of the study area showing the locations of previously published sites and settlements visited within the scope of KRASP (map by M. Massa).

has resulted in low visibility for sites associated with more mobile groups (for example in the steppe and highlands) and for settlements with a non-mudbrick architecture (for example mostly made of reeds/wood/stone). In addition, earlier surveys generally failed to investigate artefact scatters beyond the main mound formation of a site. However, in light of fieldwork carried out by KRASP, it is probable that most of the medium and large sites would have, at some point in time, expanded beyond the main tell/höyük (see Lawrence, Wilkinson 2015 for northern Mesopotamia). While the size and shape of the main tell can be calculated through satellite imagery and DEM analysis, information on the extent and phasing of lower settlements is generally available only for sites visited by KRASP

Given the absence of well-documented stratigraphic contexts within the study area covering the Middle Chalcolithic through to the Iron Age, the second major limitation relates to the dating of survey materials. This includes the low chronological resolution for some of the archaeological periods; for example, at present we cannot recognise sub-phases for the Late Chalcolithic, spanning over 1,000 years (see table 1). In addition, some periods (such as Early Bronze IIIb and the Early Iron Age) are very scarcely represented in the pottery record. We suspect this trend may relate more to our relatively poor understanding of ceramic time-markers associated with these phases rather than - or in addition to - a real reflection of demographic patterns (Massa et al. 2019a: 163-64). To obviate this problem we initiated a detailed chrono-typological study of the Neolithic to Iron Age pottery assemblages from the region, working on materials collected by Mellaart, French and Todd, and currently stored at the BIAA (Bachhuber, Massa 2016). This study, conducted by two of the authors (Şahin and Erpehlivan), has begun to produce results, some of which are preliminarily presented here.

The third limitation is represented by taphonomic processes that may have affected the recovery of archaeological artefacts. Geoarchaeological research in the Çarşamba delta suggests that post-Chalcolithic alluvial sediment deposition would have been minimal $(1 \mathrm{~m}$ or lower), and would not have resulted in significant masking of tell-type sites (Boyer et al. 2006: 691-94). However, particularly in the highlands, sites located on slopes/hilltops have probably been affected by wind and water erosion, while sites in intermontane valleys are likely masked by silt deposits. 
While these represent significant obstacles for evaluating the emerging archaeological patterns, we argue that it is still possible to work with this dataset by integrating and accounting for these gaps when interpreting our results.

\section{Natural landscapes}

Our understanding of the Holocene climatic history of the Konya and Karaman plains is supported by a series of different proxies such as lake sediments, cave speleothems and dendroclimatic samples within a $200 \mathrm{~km}$ radius from this region. These include the Konya palaeolake (Roberts 1980; Karabıyıkoğlu, Kuzucuoğlu 1998), Beyşehir, Eski Acıgöl, Tecer and Nar lakes (Eastwood et al. 1998; Kuzucuoğlu et al. 2011; Roberts et al. 2016), the Kocain stalactite record (Göktürk 2011) and several dendroclimatic samples from Konya-Karahöyük dateable to the early second millennium BCE (Manning et al. 2016). Collectively, these climatic archives show a general trend toward warmer temperatures and diminished rainfall starting around $5000 \mathrm{BCE}$ and accelerating after the socalled 4.2ka event (ca 2000 BCE). During the Middle to Late Bronze and Iron Ages, the region would have experienced temperatures and rainfall regimes that are comparable with present conditions. Multi-decadal data from several meteorological stations show a modern yearly rainfall average ranging from $240 \mathrm{~mm} /$ year at the centre of the Konya plain to $340 \mathrm{~mm} /$ year at the piedmont of the Taurus mountains, with several years falling well below the $250 \mathrm{~mm} /$ year threshold for dry agriculture (Türkeş 1996: table II; Rosen, Roberts 2006: fig. 4.2).

These data show that, during the Late Holocene, the Konya-Karaman plains formed the driest region in Anatolia and were characterised by a semi-arid landscape that experienced cyclical, but to some extent unpredictable, episodes of rainwater scarcity. In such an environment, we suggest that the inhabitants of the Konya and Karaman plains would have needed to develop relatively sophisticated water-management strategies at an early stage, probably earlier than any other region of the Anatolian peninsula.

The palaeoenvironmental proxies collected from sediment sequences of the Çarşamba delta (Boyer et al. 2006; Ayala et al. 2017) and various lakes/marshes in the region (Roberts 1980; Bottema, Woldring 1984; Karabıyıkoğlu, Kuzucuoğlu 1998) show that the local hydrographic landscapes also underwent dramatic changes throughout the Holocene. During the early Holocene (ca 9500-5000 BCE), standing water was interspersed throughout the region, but after ca 5000 BCE drier climatic

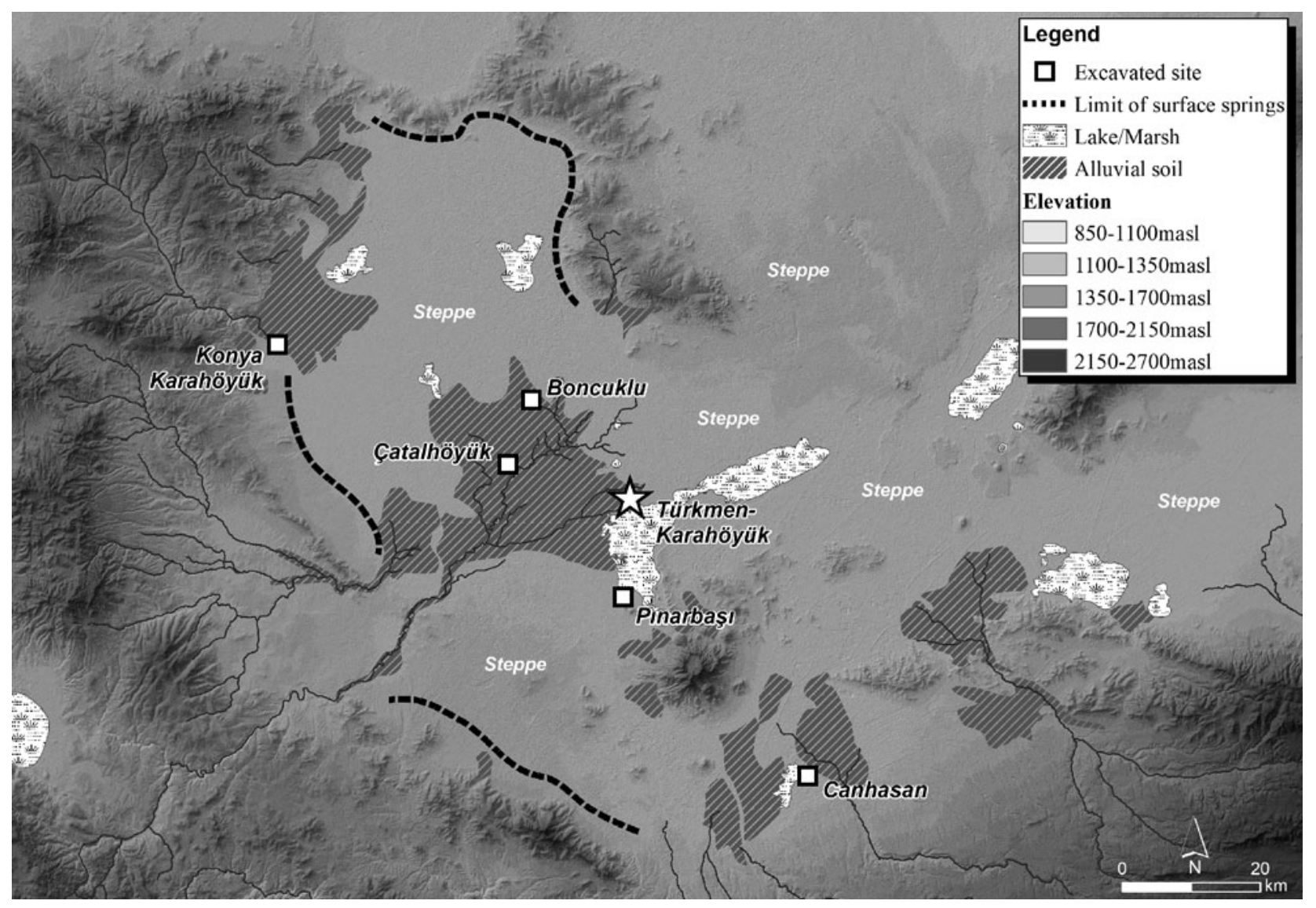

Fig. 2. Major ecological niches within the Konya and Karaman plains (map by M. Massa). 
conditions prevailed and considerably reduced the extent of marshland. Bioarchaeological records show that, as marshlands receded, most of the area previously under water became covered with steppe throughout the mid- and late Holocene (Bottema, Woldring 1984; Woodbridge et al. 2019). Contemporary with settlement at Çatalhöyük and Canhasan III, the mountainous landscapes that encircle the Konya and Karaman plains were characterised by oakdominated semi-arid woodlands; after the mid-Holocene, however, forest cover was considerably reduced by human activity (Kabukçu 2017).

Based on water availability, vegetation cover and slope (related to the ability to farm), we have defined four major ecological niches within the region (fig. 2).

(1) Alluvial fans: mostly created by watercourses originating in the Taurus mountains. The Çarşamba-May delta complex, located at the centre of the Konya plain, represents the most extensive alluvial basin in the region, but smaller fans can be found at the interface between the Boz and Taurus mountains and the plains.

(2) Spring-fed piedmont: a narrow strip also at the plain-mountain interface, where runoff water collects in small pools.

(3) Steppe: covering most of the plains that are not watered by springs and rivers.

(4) Highlands: rugged orographic features surrounding the Konya and Karaman plains, with higher yearly rainfall averages and more extensive arboreal cover, but with arable land restricted to small intermontane valleys.

The boundaries between these four zones are likely to have changed in the course of the mid- to late Holocene, due not only to climatic changes but also to landscape modification resulting from human activity, for example deforestation and arboriculture (Eastwood et al. 1998) and irrigation (see below). During the Bronze and Iron Ages, the scarcity of rainwater in the region would have resulted in a greater reliance on runoff water, and therefore proximity to rivers and canals would have been an essential factor in settlement-location choices. The large alluvial basins of the Konya and Karaman plains were vital agricultural catchments that could have sustained dense populations living within major centres (see 'Inhabited landscapes', below). Conversely, areas with limited or no access to watercourses were too arid to sustain dry farming, and communities inhabiting these steppes would likely have relied more on animal husbandry (see Ur, Hammer 2009 for northern Mesopotamian contexts).

\section{Inhabited landscapes}

The ongoing analysis of KRASP sites and legacy survey datasets is beginning to inform demographic trends and the locations of major sites within the area from the Early Bronze Age (EBA) to the end of the Iron Age (table 1).

\begin{tabular}{ll} 
Absolute date & Regional phasing \\
\hline $3200-2800$ BCE & Early Bronze Age I (EB I) \\
2800-2500 BCE & Early Bronze Age II (EB II) \\
2500-2200 BCE & Early Bronze Age IIIa (EB IIIa) \\
2200-1950 BCE & Early Bronze Age IIIb (EB IIIb) \\
1950-1650 BCE & Middle Bronze Age (MBA) \\
$1650-1400$ BCE & Late Bronze Age I (LBA I) \\
$1400-1200$ BCE & Late Bronze Age II (LBA II) \\
$1200-900$ BCE & Early Iron Age (EIA) \\
$900-600$ BCE & Middle Iron Age (MIA) \\
$600-300$ BCE & Late Iron Age (LIA) \\
$300-30$ BCE & Hellenistic
\end{tabular}

Table 1. The relative chronology of the Konya-Karaman plains.

With all the caveats noted above, we can observe that sedentary settlements were established at different times in the four main ecological niches. The earliest tell sites can first be observed during the late ninth millennium BCE within the Çarşamba river delta (at Boncuklu; Baird et al. 2018) and at least from the late seventh millennium BCE onward in other alluvial basins (for example at Alkaran Höyük; Bahar, Koçak 2004: 14). The early sixth millennium BCE saw an expansion of communities within the delta and the first appearance of höyük sites in the spring-watered piedmont and the intermontane valleys of the Taurus range (Bahar, Koçak 2004; Baird 2006). It is only from the EBA onwards that intermontane sites become more common. On the other hand, sedentary settlement in the steppe region north and east of the Çarşamba-May delta complex is not observed to any significant extent before the mid-first millennium BCE, when the area was first settled, probably following a large-scale irrigation project (see 'Irrigated landscapes', below).

From the Neolithic through to the end of the Iron Age, settlement sizes generally ranged from 3 ha to 8 ha, with only a small portion (16\%) over 8 ha. A comparison between site sizes in the different ecological niches (fig. 3 ) shows that the largest sites and the majority of sedentary (tell) settlements were located on the plains and, more specifically, in the well-watered alluvial basins (figs 1, 4). Despite sustained research, KRASP has so far been unable to record definite occupation of the Boz mountains at any point during the pre-Hellenistic period, beyond early prehistoric camp sites and fortified hilltop sites (see 'Defensive landscapes', below). Today, the highland landscape of the Boz mountains remains mostly uninhab- 
Massa et al. | Urbanisation and early state formation on the Konya and Karaman plains

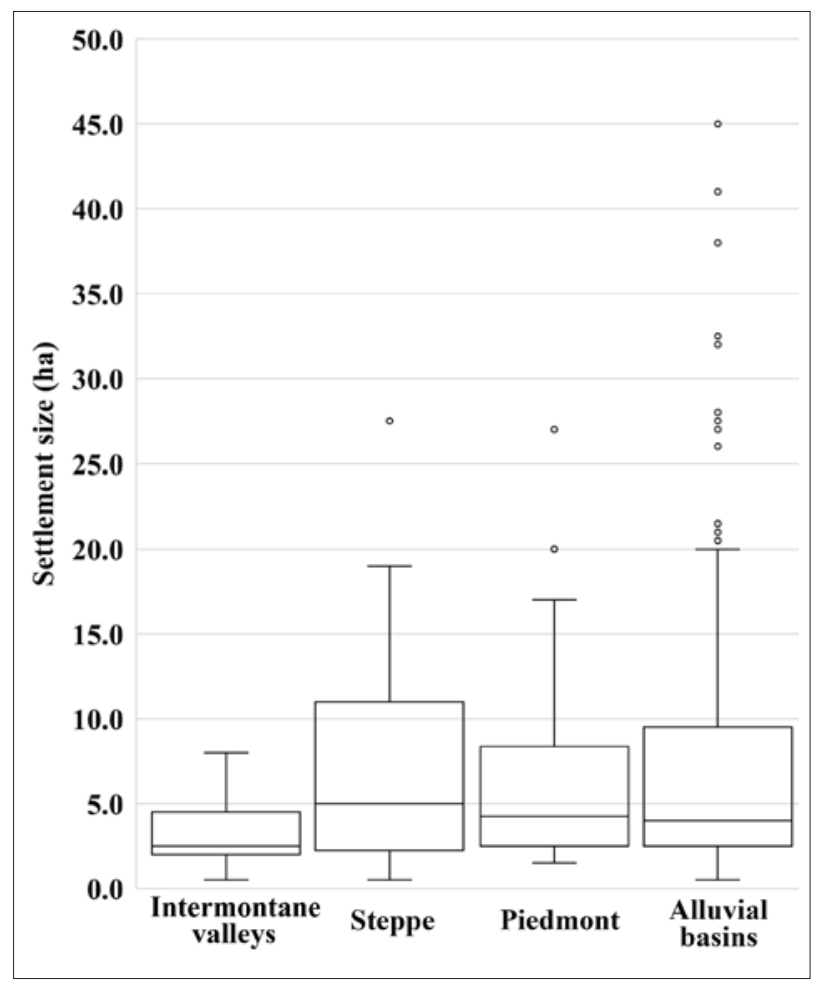

Fig. 3. Box-and-whisker-plot of estimated settlement size for pre-Hellenistic sites in the Konya and Karaman regions, according to ecological niche; $n=256$ sites; TürkmenKarahöyük (ca 125ha) is not included.

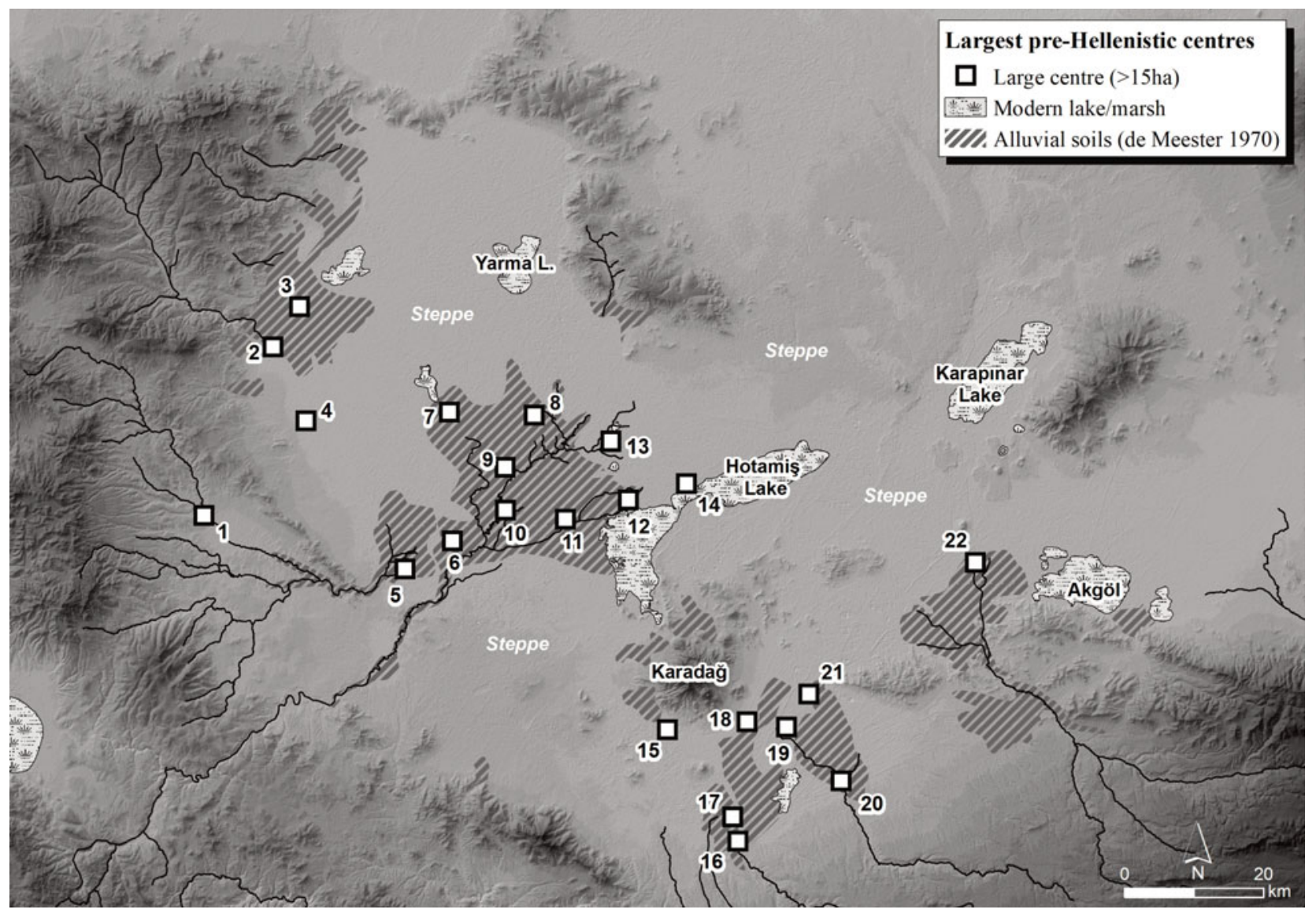

Fig. 4. Location of the largest pre-Hellenistic mounded sites in the study region (for site numbers, see table 2) (map by M. Massa). 
ited, with the exception of occasional shepherds' huts that are seasonally occupied. However, as shown by Bahar's surveys, there is better evidence for pre-Hellenistic settlement in the western Taurus mountains, ranging from mounded settlements in small intermontane valleys, to slope sites, fortified hilltops, peak sanctuaries and mortuary areas (Bahar, Koçak 2004). With few exceptions, intermontane settlements can be characterised as small villages (fig. 3), and it is likely that the highlands and uplands would have been as sparsely populated in the past as they are today.

Furthermore, while it is difficult to extrapolate the maximum sizes of sites without an intensive field survey, at least 22 sites larger than 15 ha and with a major occupation before the end of the Late Iron Age (LIA) can be identified with some confidence in the study area (table 2, fig. 4). Although many of these centres appear to have achieved regional prominence only during a relatively short period of time, most of them show evidence for repeated occupation throughout the prehistoric and early historic periods (see figs 5 and 6 for sites revisited by KRASP). They are mostly concentrated within the alluvial fans and appear evenly distributed at ca $7-11 \mathrm{~km}$ apart from each other. The presence and density of large population centres is, in itself, a witness to the significant agricultural capacity of the Konya and Karaman plains, which together form one of the largest agricultural basins in modern Turkey. This was likely a major factor in the growth of Çatalhöyük East, as it has become identified as one of the largest sites in the Neolithic Near East (ca 16ha; Der, Issavi 2017). Çatalhöyük represents a very early case study for a large-scale aggregated settlement, and it appears to have sustained much of the population of the Çarşamba alluvium for over 1,000 years (Baird 2006;

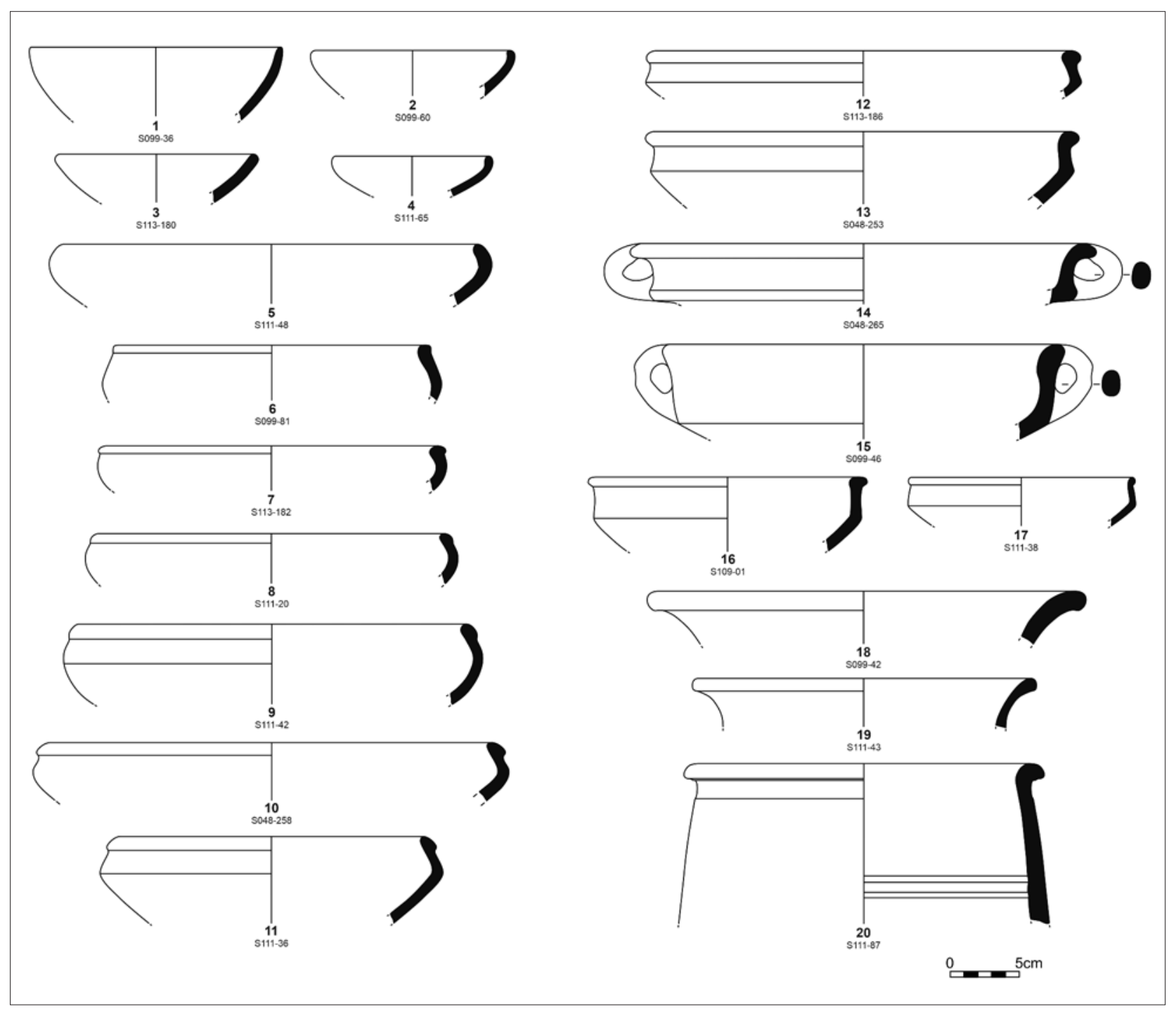

Fig. 5. Middle Bronze Age ceramic assemblages from major centres revisited by KRASP: Sirçalı Höyük (1-2, 6, 15, 18); Seyithan Höyük (3, 7, 12); Domuzboğazlayan Höyük (4-5, 8-9, 11, 17, 19-20); Büyük Aşlama Höyük (10, 13-14); Alibeyhöyüğ̈̈ (16) (drawings by F. Arslan, E. Incaman and S. Ün). 


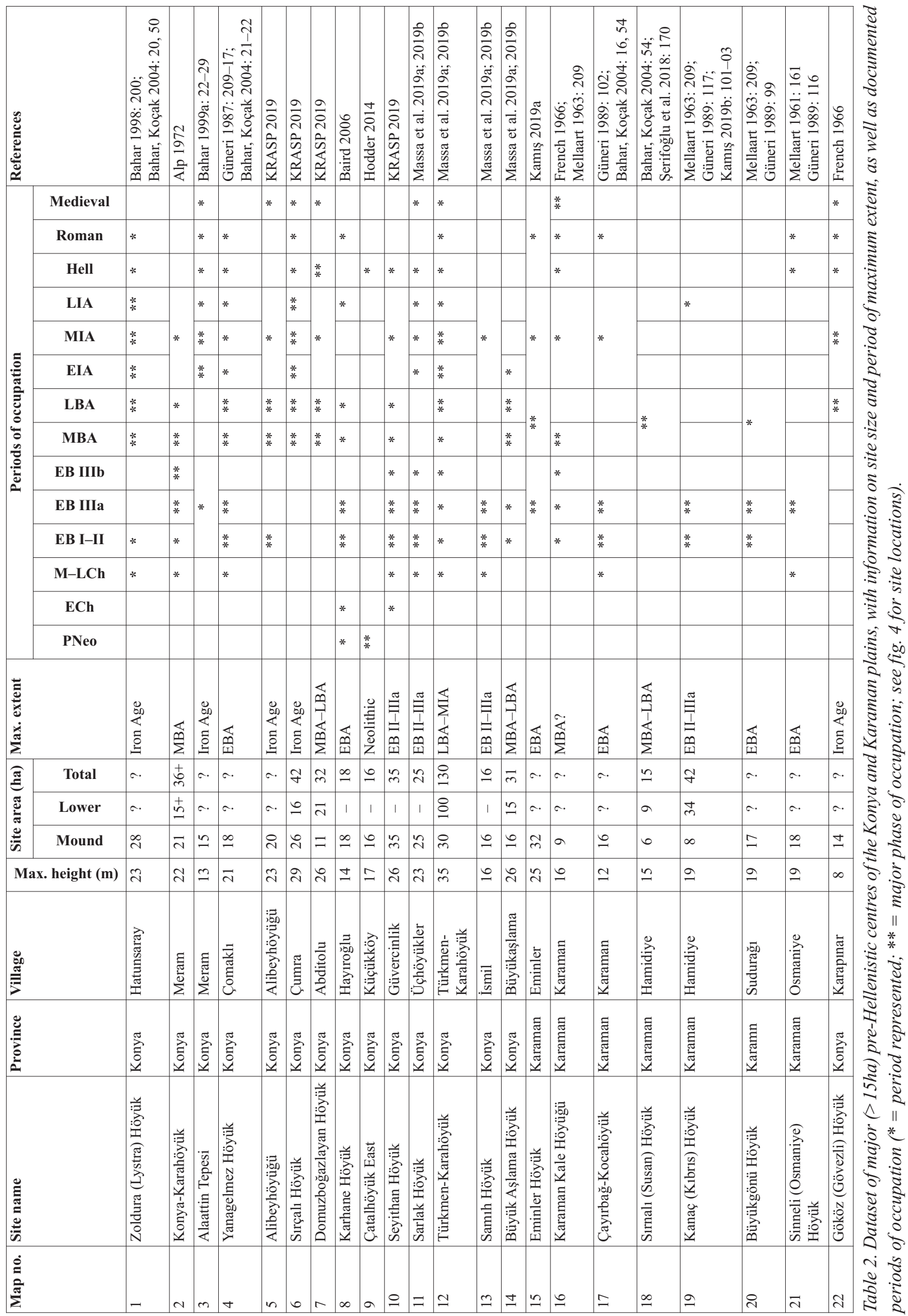




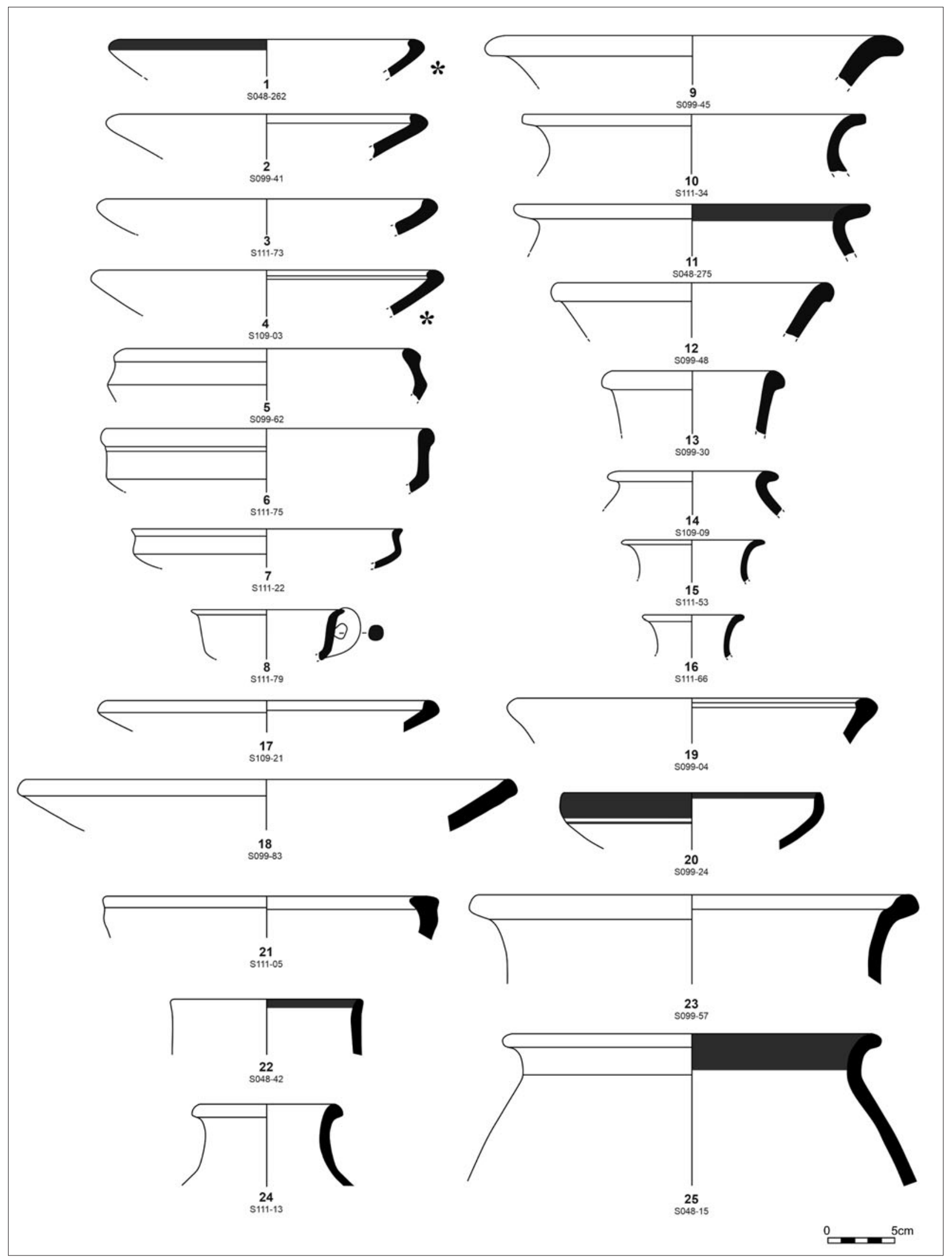

Fig. 6. Late Bronze Age (1-16), Early (18, 21), Middle (17, 19, 23-24) and Late (20, 22, 25) Iron Age ceramic assemblages from major centres revisited by KRASP: Büyük Aşlama Höyük (1, 11, 22, 25); Sirçalı Höyük (2, 5, 9, 12-13, 1820, 23); Domuzboğazlayan Höyük (3, 6-10, 15-16, 21, 24); Alibeyhöyüğü (4, 14, 17) (drawings by F. Arslan, E. Incaman and $S . \ddot{U} n ; *=$ Drab Ware). 
Hodder 2014). Despite its evident success, however, this settlement model was not replicated elsewhere on the Konya and Karaman plains. In fact, sites of comparable size did not reappear in the region until three millennia later, when Kanaç/Kıbrıs Höyük (ca 42ha), Seyithan Höyük (ca 35ha), Eminler Höyük (ca 32ha) and Sarlak Höyük (26ha), among others, seem to have reached their largest extent between ca 2800 and 2300 BCE (table 2).

Prehistoric settlements appear to have been confined within mound formations, and the relatively homogenous accretion of anthropogenic deposits within mounds suggests gradual population growth and stability over several centuries. Conversely, from the (late?) EBA onwards it is possible to detect occasionally the presence of ceramic scatters beyond the tells (for example at Seyithan Höyük; Baird 1999: 14), indicative of more dispersed lower settlements around them. As a preliminary proposal, we suggest that these formations may represent a relatively rapid population growth, possibly in connection with the process of urbanisation (see Lawrence, Wilkinson 2015 for northern Mesopotamia). In the Middle Bronze Age (MBA), we observe unusual flat-topped, steep-sloped mounds whose shapes suggest the presence of soil-retaining fortification walls (see Mellaart 1958: 317 for the concept). During the Late Bronze Age (LBA), the flat-topped site of Türkmen-Karahöyük expanded to encompass an area of well over 100 ha, probably three times the size of the second-biggest site in the region (Kanaç Höyük at 42ha; Kamış 2019b: 101; for TürkmenKarahöyük, see Osborne et al. 2020, this volume). Beginning in the LIA, the mounds had begun to be abandoned in favour of settlement on the plain that surrounded them. This trend is vividly observed in subsequent post-Iron Age settlement patterns, which include KRASP's identification of very small $(30-40 \mathrm{~m}$ in diameter) farmsteads forming low (2-3m in height) mounds surrounding much larger (and older) tells. This pattern, with origins we suggest in the LIA, points towards more dispersed settlement and less concern, compared with previous periods, with the security and defensibility of individual sites (see Massa et al. 2019a: 170). In the discussion below, we address how these data reflect the inclusion of the Konya and Karaman plains within larger (imperial) territorial entities.

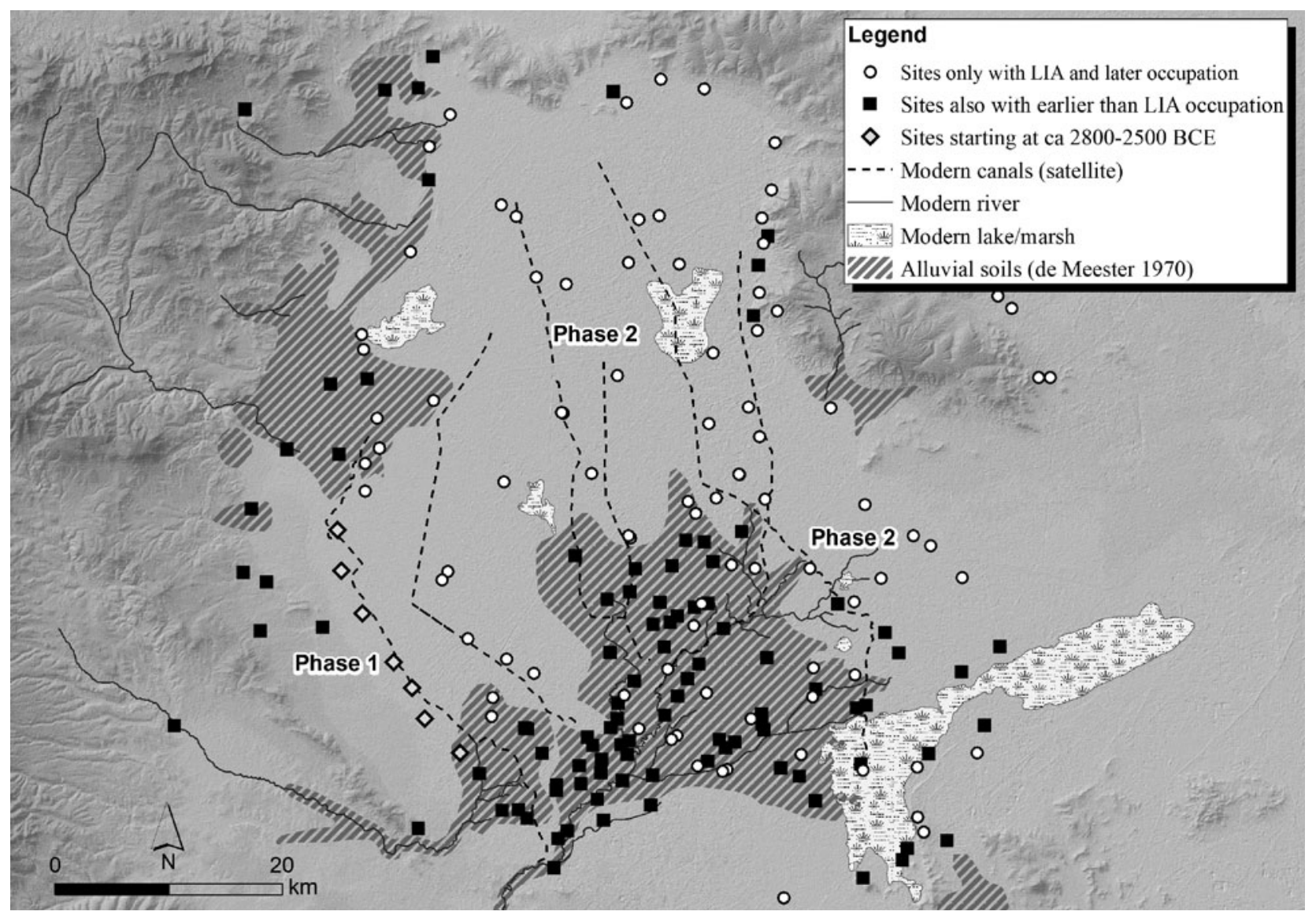

Fig. 7. Locations of surveyed sites in relation to the extent of alluvial soils and the paths of major modern canals. Site dating indicates that the earliest mounded settlements on the steppe occurred in the mid-third millennium BCE (Phase 1), and more prominently after the sixth century BCE (Phase 2) (map by M. Massa). 


\section{Irrigated landscapes}

At what stage the farmers of the Konya and Karaman plains began actively to modify their surrounding hydrographic landscapes in order to expand agricultural land and settlement is a matter of debate. In the Levant and northern Mesopotamia, the presence of small-scale ditches, dykes and artificial ponds points to small-scale water management already in the ninth millennium BCE (Charbonnier 2019), but no such contemporary evidence has surfaced yet for the Konya and Karaman plains.

Only from the Early Bronze (EB) II period (ca 2800$2500 \mathrm{BCE}$ ) onward does secondary evidence suggest the possible presence of artificial irrigation channels. A series of seven settlements - Yavşan Höyük, Saksak Höyük, Direyük, Çarıklar Höyük, Sivrice Höyük, Yanagelmez (Çomaklı) Höyük, Alakova Höyük - aligns conspicuously from south to north from the northernmost fringes of the May delta in the direction of modern Konya (fig. 7, Phase 1). These sites were all first inhabited in the Early Bronze II period (fig. 8.1-3; also Bahar, Koçak 2004: 21-22) and continued to be inhabited throughout the second millennium and into the Iron Age. Their appearance on the steppe appears contemporaneous (at least in ceramic terms), in a zone that had not supported previous settlement, and their alignment is closely overlapped by a modern irrigation canal, which suggests the possible reuse of an older waterway. The location of these sites therefore suggests the existence of a $25 \mathrm{~km}$-long artificial channel that drew water from the May river. This hypothesis is supported by geoarchaeological studies around Çatalhöyük which indicate that the flow of the Çarşamba river appears to have been altered to limit seasonal flooding (likely through artificial channelisation) at least from the late third millennium BCE onwards (Boyer et al. 2006: 687-89; Ayala et al. 2017: 41-42). A new sub-project of KRASP is currently investigating the early stages of water management on the Konya plain through remote sensing and a new geological coring programme. If confirmed, the line of EB II sites would amount to the earliest evidence for canal irrigation systems in western and central Anatolia.

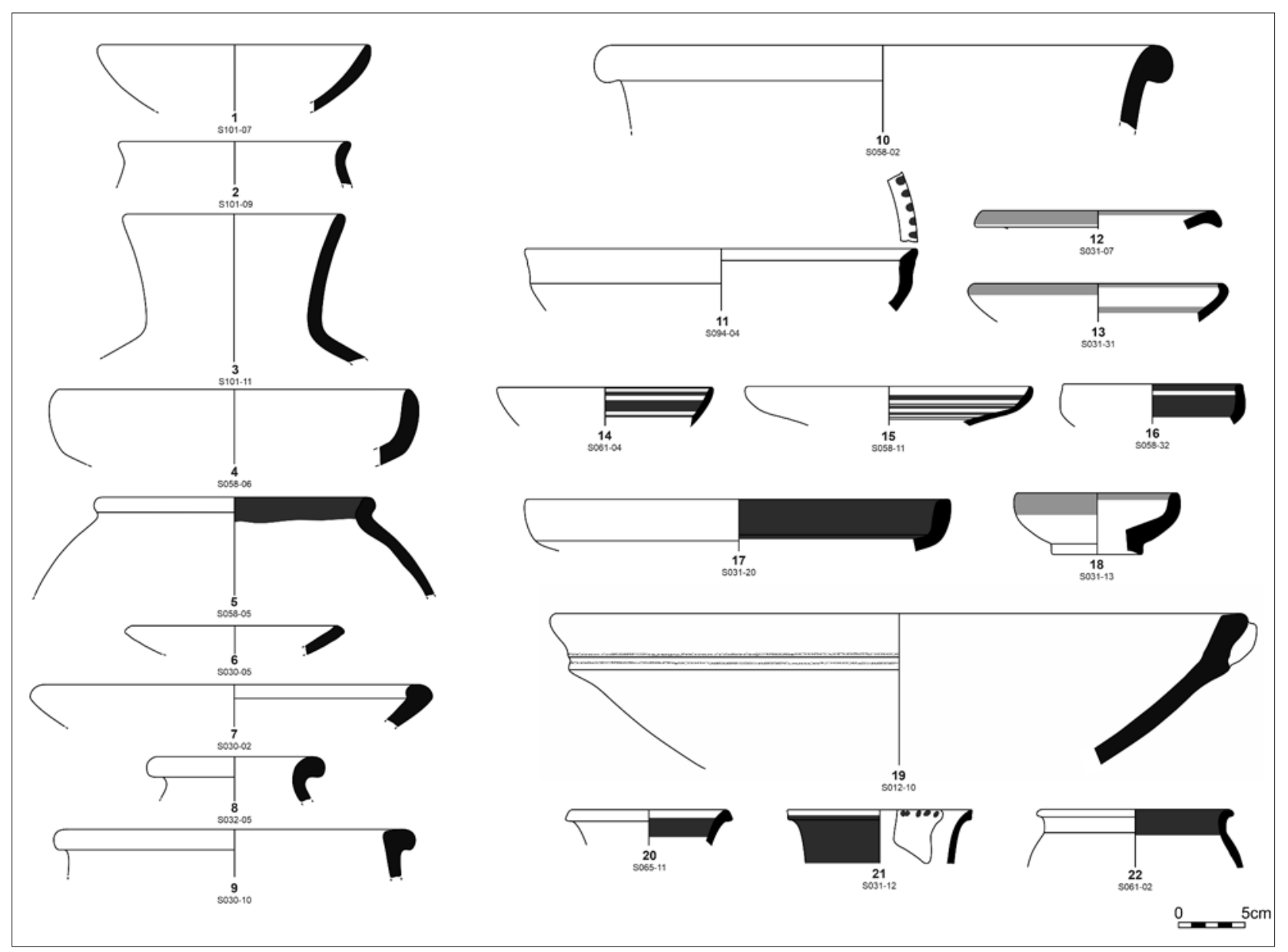

Fig. 8. Early (1-3), Middle (4-5) and Late Bronze Age (6-10), Early Iron Age (11) and Late Iron Age (12-22) ceramic assemblages from mounded sites on the steppe revisited by KRASP: Yavşan Höyük (1-3); Eşek Tömeği Höyük (4-5, 10, 15-16); Hamam Höyük (6-7, 9); Hayıroğlu-Çatalhöyük (8); Küllü Höyük (11); Turfalı Höyük (12-13, 17-18, 21); Ortakonak Höyük (14, 22); Kilisetepe Höyük (19); Göçü Höyük (20) (drawings by F. Arslan, E. İncaman and S. Ün). 
Currently, the earliest evidence for irrigation in Anatolia is from Kültepe/Kanesh (200km to the east), where palaeobotanical analysis suggests the presence of irrigated landscapes in the Early Bronze III (ca 2500-1950 BCE; Fairbairn 2014: 184, 189). From later periods, textual evidence from both Kültepe/Kanesh (1950-1750 BCE) and the Hittite capital of Hattuša (1600-1200 BCE) records the irrigation of both gardens and fields (Dercksen 2008; Marazzi 2008), while Hittite dams and water pools are archaeologically and textually well attested (for example Harmanşah 2014: 54-82).

For the LBA and Early Iron Age (EIA), KRASP has recorded a limited expansion of settlement to the fringes of the Çarşamba river delta (see fig. 8.6-11 for dateable materials from these sites), which supports our assessment of a possible minor expansion of irrigation canals in this area.

We observe the next major phase of probable irrigation development in the mid-first millennium BCE. Evidence includes a dramatic northern expansion of small farming settlements (i.e. mound formations) in an arid landscape that was previously devoid of sedentary occupation (fig. 7, Phase 2). KRASP's ceramic analysis indicates that the earliest sites in this area can be dated to the LIA (fig. 8.1216), while the only pre-LIA site (Eşek Tömeği Höyük; fig. $8.4-5,8.10)$ is probably associated with an ephemeral expansion of the Yarma lake. Like the alignment of the EBA sites noted above, many of these LIA settlements follow the (south to north) courses of modern irrigation canals, supporting our interpretation that older watercourses are being reused in the modern irrigation system. Below, we address the relationship between this trend and Achaemenid imperial interventions in this region.

\section{Defensive landscapes}

Bahar and his team were the first to investigate the large number of fortified hilltop sites found in the highlands surrounding the Konya-Karaman plains (Bahar, Koçak 2004; Karauğuz, Kunt 2004). Hilltop sites are located on isolated orographic features that nevertheless have easy access to the valley floor (a 10-15-minute descent at most in our experience). They are generally located above the major passes into and out of the lowlands, marked by modern inter-city roads. Most of them are multi-period, although it is unlikely they would have been inhabited continuously. Table 3 shows how, while some Chalcolithic occupation of hilltop sites has been recorded, most of them can be dated to the EBA or later (fig. 9; Bahar, Koçak 2004; Massa et al. 2019a: figs 9-10; 2019b: figs 3-5). In addition, the majority have evidence of circuit walls, often strengthened by bastions, towers, glacis and sometimes a second circuit wall. Visible defensive structures can all be dated generally to the Iron Age, Hellenistic and Roman periods on the basis of masonry techniques (fig. 10; cf. Karauğuz, Kunt 2004).
The defensive architecture clearly demonstrates a military function for these sites during the first millennium $\mathrm{BCE}$ and raises the question whether the same sites served similar functions in earlier periods. It is worth emphasising, that, without exception, these sites are located on exposed hilltops with limited access to water and thus are unlikely locations for normal residential settlement. During the Iron Age, at least two hilltop sites at the margins of the Konya plain were locales for cultic activity (Kızıldağ Kalesi and Karadağ, see below). Yet, since there is no compelling evidence for Bronze Age ritual (i.e. architectural elements, inscriptions, reliefs, vessel forms) the greater likelihood is that they were used also as fortified hilltops in earlier periods, probably as early as the EBA.

The size range of the fortified enclosures within the circuit walls and the complexity of defensive architectural elements suggest differing defensive functions for these hilltop sites. Fortified hilltops in the smallest category (for example Bozdağ at ca $20 \mathrm{~m} \times 20 \mathrm{~m}$ ) were probably used as watchtowers, whilst the largest (for example Seçme Kalesi at ca $290 \mathrm{~m} \times 130 \mathrm{~m}$ ) were likely strategically important fortresses. KRASP has also identified dense material scatters beyond the fortifications of some of the main strongholds (for example Seçme Kalesi, Kana Kalesi), showing the likely existence of garrisons around them. While most hilltop sites are located close to the stretch of valley floor that they were arguably built to restrict access to, some are located on mountain tops that command a wide view but would have been less effective for launching forays into the valley below (for example Gevale Kalesi).

Many of the largest Bronze Age and Iron Age settlements of the Konya and Karaman plains would probably also have been enclosed by defensive walls. In addition to evidence for an excavated outer MBA city wall at KonyaKarahöyük (Alp 1972: 11-12), circuit walls on upper mounds can be identified both in satellite imagery and through ground inspection (see the discussion of flattopped sites in the section on 'Inhabited landscapes').

The considerable increase in defensive architecture during the EBA on the Konya-Karaman plains is likely connected with the rise in organised violence and the preoccupation with site defensibility, a trend that can be observed more broadly across Anatolia from the late fourth millennium BCE onwards (Erdal, Erdal 2012; Massa 2014; Ünlüsoy, Çilingiroğlu 2017). The high frequency of warfare is further recorded by MBA textual evidence. The Old Assyrian tablets (ca 1950-1740 BCE) often describe conflict between polities, as well as patrols and fortresses protecting major trade routes from brigands and adversarial armies (Barjamovic 2011: 19-33; Barjamovic et al. 2012: 43-52). Furthermore, the concept of geographically defined political borders is clearly expressed in the Hittite period, 


\begin{tabular}{|c|c|c|c|c|c|c|c|c|c|c|c|c|c|c|c|c|c|c|c|c|c|c|c|c|c|}
\hline \multicolumn{2}{|c|}{ 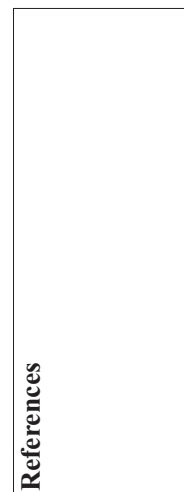 } & 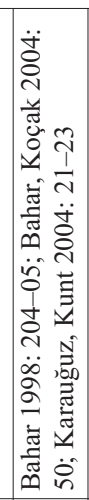 & 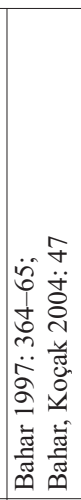 & 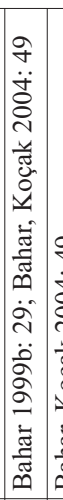 & & 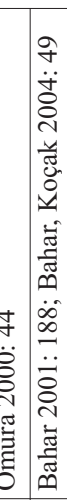 & 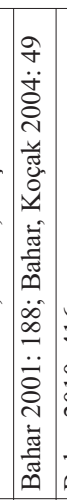 & & 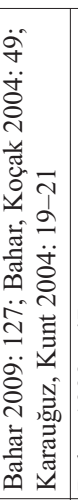 & 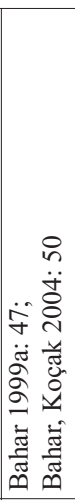 & 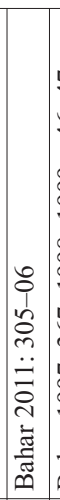 & 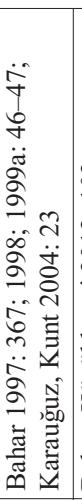 & 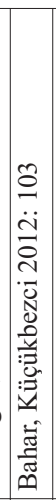 & 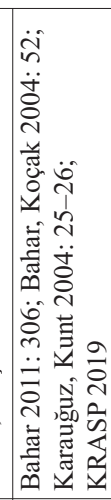 & 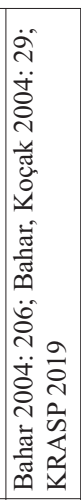 & 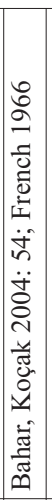 & 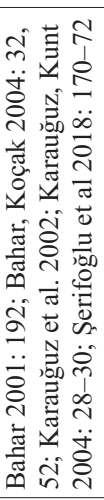 & 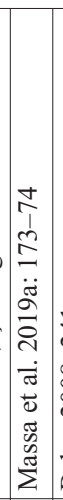 & & 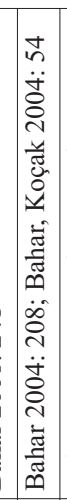 & 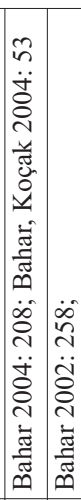 & 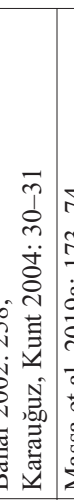 & & 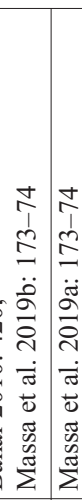 & 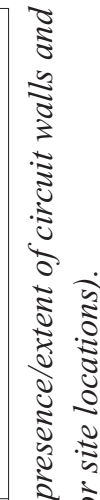 \\
\hline \multirow{9}{*}{ 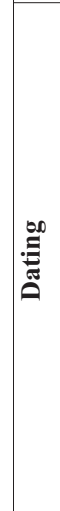 } & Roman & $\star$ & $x$ & $x$ & & 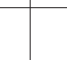 & $x$ & $\times$ & & $x$ & $x$ & $\star$ & $\star$ & & & & & & $x$ & $x$ & $*$ & & & & \\
\hline & Hell & $\star$ & & $x$ & & $\star$ & $\times$ & & $\rtimes$ & $x$ & & * & & $\star x$ & & & $x$ & & & & $x$ & & $x$ & & \\
\hline & LIA & $\star$ & $x$ & & $\star$ & $x \times$ & & & $\star$ & * & & * & & * & $\star$ & & $x$ & \multirow{3}{*}{ * } & & & $* x$ & $<$ & $* x$ & \multirow{3}{*}{$\star$} & \\
\hline & MIA & & & & & & & & & & & $\star$ & & $\star$ & * & & $x$ & & & & $x$ & 4 & & & \\
\hline & EIA & & & & & & & & & & & * & & $\star$ & & & $x$ & & & & & & & & \\
\hline & LBA & * & $\star$ & & & & & & & $x$ & & * & & × & $\star$ & $x$ & $x$ & & & $x$ & & $x$ & & \\
\hline & MBA & & * & & $\star$ & $\star$ & & & & & & & & $\star$ & $\star$ & $x$ & $x$ & & & * & & & 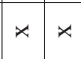 & & \\
\hline & EBA & & $\star$ & $x=$ & $\rtimes$ & & $\star$ & $x \times$ & $\star$ & & $\star$ & & $\star$ & & $\star$ & & & & \begin{tabular}{|l|l|}
$\times$ & $\times$ \\
\end{tabular} & & 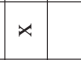 & & & & \\
\hline & Chalc & & & & & & $\star$ & & & & $x$ & & * & & & & & & & & & & & & \\
\hline \multicolumn{2}{|c|}{$\begin{array}{l}\text { Above valley } \\
\text { floor (m) }\end{array}$} & 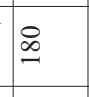 & I & $\because 8$ & 8 & m & F & & in & in & ন : & $R$ & 6 & 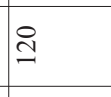 & సิ & $m$ & 8 & 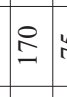 & $\curvearrowleft \approx$ & I & is 8 & 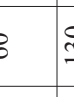 & 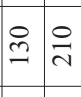 & ¿ & \\
\hline \multicolumn{2}{|r|}{ Outer site } & $\ddot{z}$ & $\ddot{z}$ & 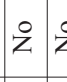 & \& & 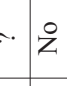 & 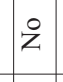 & $\stackrel{y}{2}$ & $\underbrace{2}_{i}$ & r. & $\stackrel{2}{z}$ & 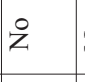 & 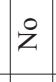 & 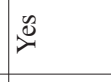 & z & a. & $y^{\infty}$ & 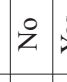 & $\underbrace{\circ}$ & $\ddot{z}$ & $\stackrel{0}{2}$ & $>$ & $\stackrel{\substack{0 \\
\hdashline}}{z}$ & z & \\
\hline \multicolumn{2}{|c|}{ 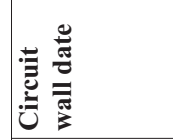 } & & & & & & & 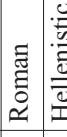 & 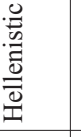 & & & & 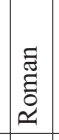 & $\overleftrightarrow{\Sigma}$ & & & $\$$ & 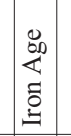 & & & & & 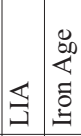 & 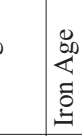 & 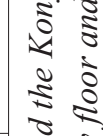 \\
\hline \multicolumn{2}{|c|}{ 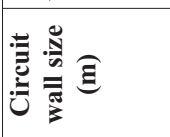 } & r. & {$\left[\begin{array}{l}n \\
n \\
x \\
0 \\
0 \\
n\end{array}\right.$} & 1 & 1 & । & $\begin{array}{l}8 \\
8 \\
x \\
2 \\
9 \\
9\end{array}$ & 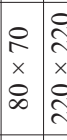 & $\begin{array}{l}\text { ते } \\
x \\
\text { ते } \\
\text { ते }\end{array}$ & 1 & 1 & $\begin{array}{l}0 \\
\infty \\
x \\
0 \\
\infty \\
\infty\end{array}$ & \begin{tabular}{|l|} 
\\
$n$ \\
$x$ \\
0 \\
0 \\
$m$
\end{tabular} & 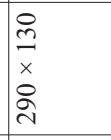 & $\begin{array}{l}8 \\
8 \\
\times \\
0 \\
-\end{array}$ & 1 & $\begin{array}{l}8 \\
\frac{8}{x} \\
x \\
6 \\
3\end{array}$ & 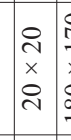 & \begin{tabular}{|l|l} 
& \\
& \\
$x$ & 1 \\
0 & 1 \\
0 & \\
\end{tabular} & 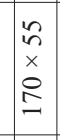 & । & & \begin{tabular}{|l|l} 
fo & 8 \\
$x$ & + \\
$x$ \\
0 & 8 \\
0 & 8
\end{tabular} & $\begin{array}{l}q \\
q \\
x \\
i n\end{array}$ & \\
\hline & 蒿 & 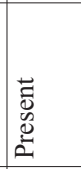 & 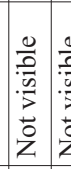 & & 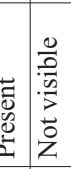 & 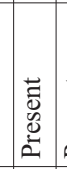 & 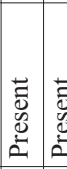 & 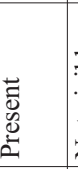 & $\begin{array}{l}0 \\
\frac{0}{0} \\
: 5 \\
5 \\
0 \\
z \\
z\end{array}$ & 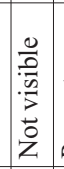 & 蒿 & 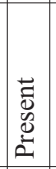 & 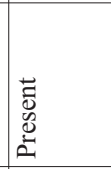 & 蒿 & 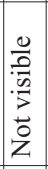 & 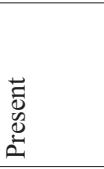 & 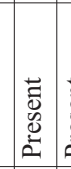 & 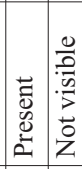 & 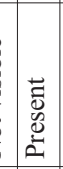 & 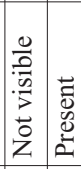 & & 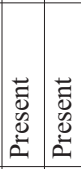 & 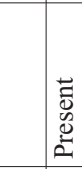 & \\
\hline & 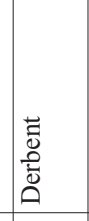 & : & 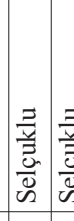 & & 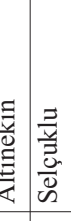 & 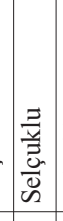 & 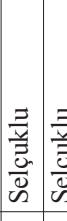 & 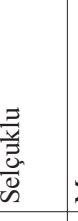 & 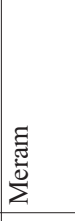 & 离 & 胥 & 离 & 咅 & 咅 & 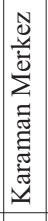 & 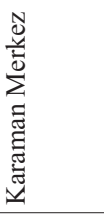 & 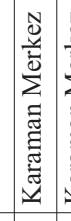 & 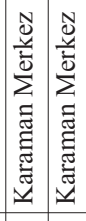 & 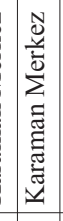 & 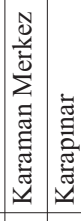 & & 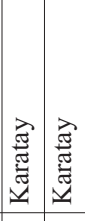 & 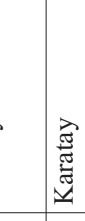 & ב⿱ \\
\hline & 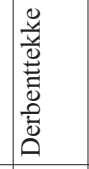 & 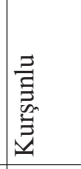 & 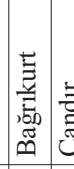 & & 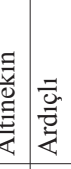 & 童 & 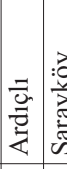 & 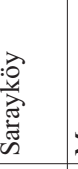 & 踣 & : & 言 & 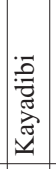 & 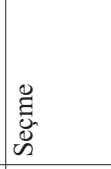 & 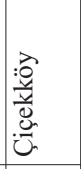 & 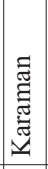 & 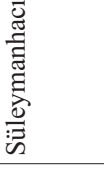 & $\begin{array}{l}\frac{0}{0} \\
\frac{\pi}{3} \\
\frac{\pi}{4} \\
\frac{\pi}{4} \\
\vdots\end{array}$ & 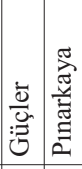 & 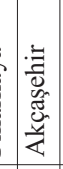 & 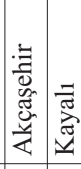 & & 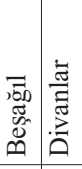 & 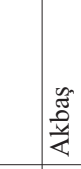 & \\
\hline & 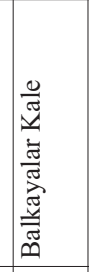 & 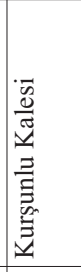 & 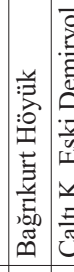 & 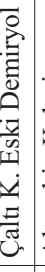 & 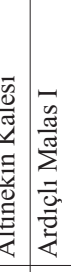 & 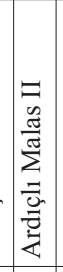 & 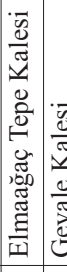 & 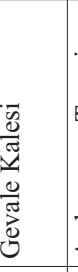 & 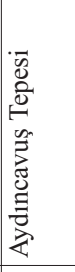 & 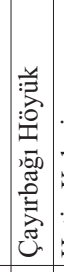 & 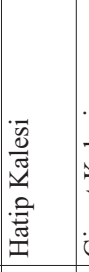 & 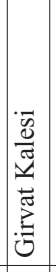 & 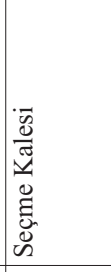 & 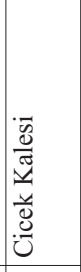 & 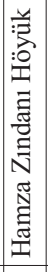 & 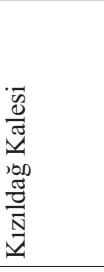 & 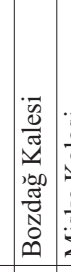 & 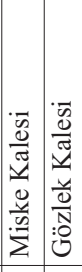 & 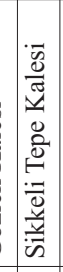 & 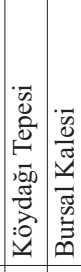 & & 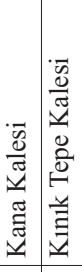 & 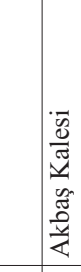 & 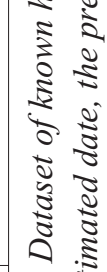 \\
\hline & - & $n$ & $m$ & & & I & & & 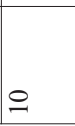 & $=$ & & 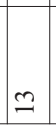 & \pm & $\because$ & & $\Xi$ & $\stackrel{\infty}{-}$ & & $\vec{\sim} \mid$ & $\pi$ & & $\underset{\sim}{ \pm}$ & & \\
\hline
\end{tabular}




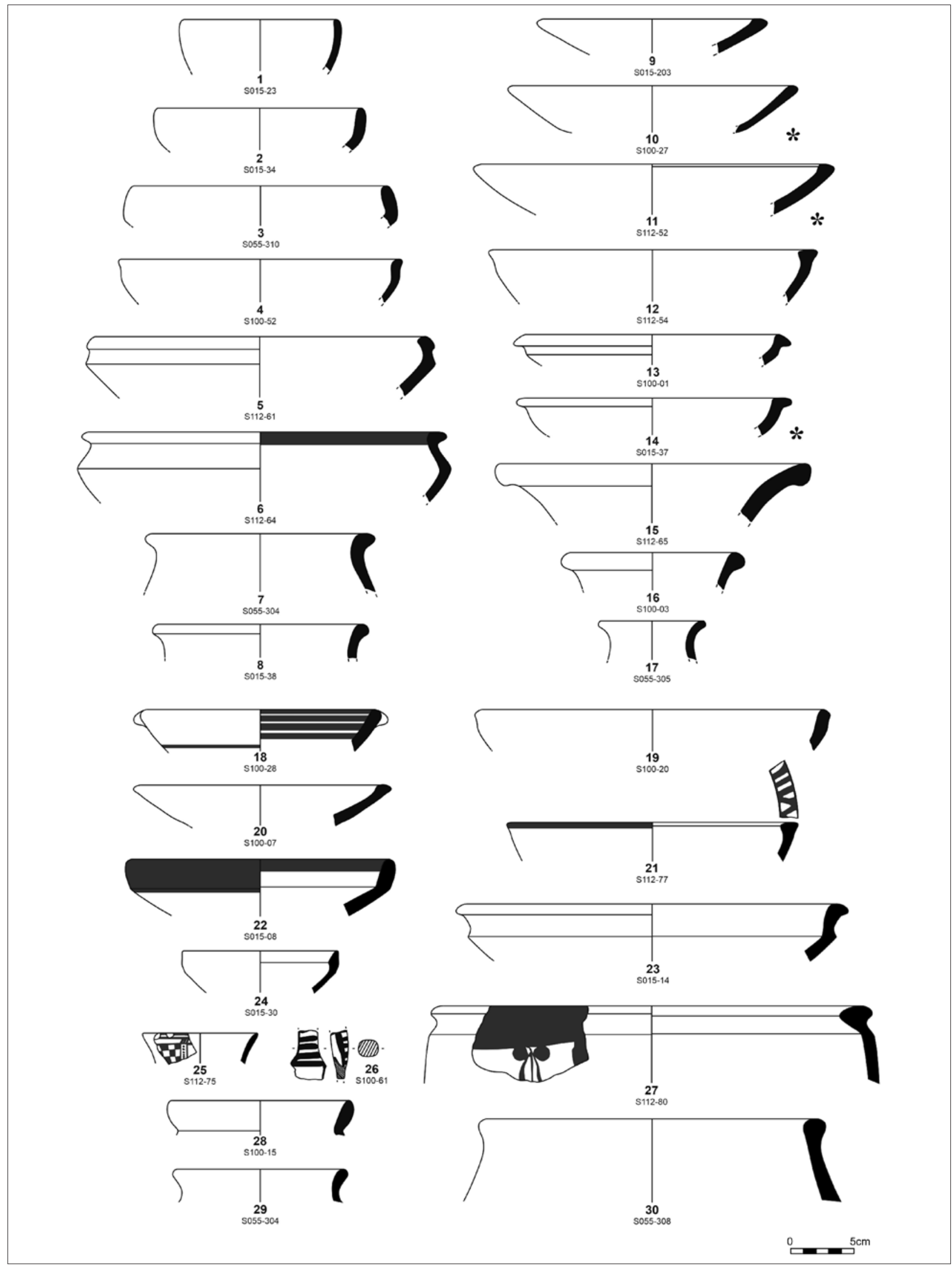

Fig. 9. Middle Bronze (1-8), Late Bronze (9-17), Middle Iron (19-21, 25-26) and Late Iron Age (18, 22-24, 27-30) ceramic assemblages from hilltop sites revisited by KRASP: Kana Kalesi (1-2, 8-9, 14, 22-24); Kinlk Kalesi (3, 7, 17 , 30); Seçme Kalesi (4, 10, 13, 16, 18-20, 26, 28); Cicek Kalesi (5-6, 11-12, 15, 21, 25, 27, 29) (drawings by F. Arslan, E. İncaman and $S$. Ün; * = Drab Ware). 

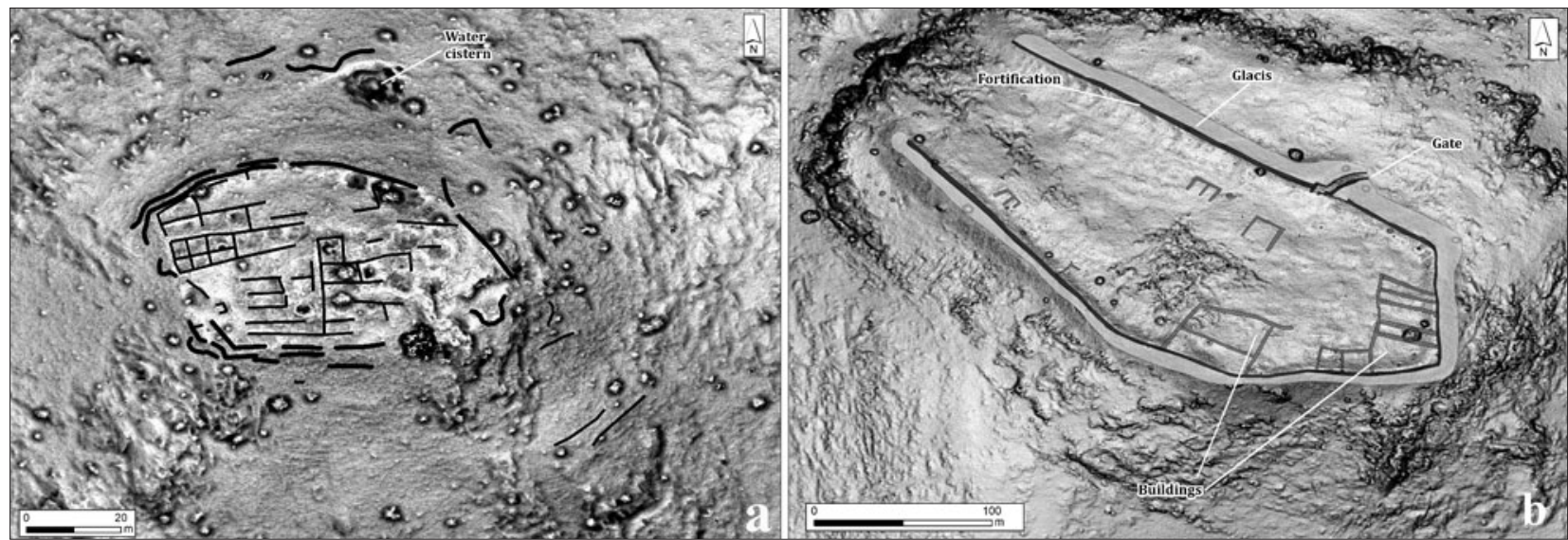

Fig. 10. (a) 3cm-resolution Digital Surface Model (DSM) of Kınık Kalesi; (b) 10cm-resolution DSM of Seçme Kalesi (elaboration by T. Lauricella).

for example in the Tarhuntašša treaties (Otten 1988; van den Hout 1995), while 'forts', 'strongholds', 'border forts' and a 'borderland' are recorded in the eight-century BCE TÜRKMEN-KARAHÖYÜK 1 (Goedegebuure et al. 2020, this volume) and TOPADA inscriptions (d'Alfonso 2019: 136-39).

We therefore propose that the large number of fortified hilltop sites detectable in the highlands around the KonyaKaraman plains may have been related to a defensive strategy aimed at protecting the densely populated lowlands from external threats. The location of fortified hilltops at the margins of the basin (fig. 11), their spatial proximity to major thoroughfares and their relative proximity to each other are all elements that suggest the existence of a defensive network likely coordinated from the seats of power in the region (see below). Considering the abundance of dateable (mid- to late?) EBA materials at these sites, it is likely that the system may first have been established in the third millennium BCE, and continued throughout the second and first millennia BCE (table 3). This hypothesis is supported by the existence of similar structures elsewhere in western and central Anatolia. Beginning in the mid-third millennium (EBA), and with more frequency in the MBA and LBA, fortifications around major valleys have been identified on the Çivril plain (Abay 2011), the Urla peninsula (Koparal 2017) and around the Marmara lake (Roosevelt, Luke 2017).

\section{Discussion}

Towards cities and states in the Early Bronze Age

In the absence of extensively excavated EBA sites on the Konya and Karaman plains, we must rely on a large volume of survey data and comparisons with better-understood regions of Anatolia to outline a period of profound transformative processes in the third millennium BCE. We believe that these processes inform the origins of the region's first cities and states, a process that culminated in the MBA (see below).

For example, there is evidence for rapid demographic growth represented in the forms of both increased site numbers and settlement sizes on the Konya and Karaman plains beginning in the EB I-II period (ca 3200-2500 $\mathrm{BCE}$ ), mirroring similar trends identified for other areas of contemporary Anatolia (Bachhuber 2015: 28-30). Although the presence/extent of lower settlements cannot be assessed in all cases, the largest sites in the region grew to 35-42ha (for example Kanaç/Kıbrıs Höyük, Eminler Höyük, Seyithan Höyük; see table 2). By way of comparison, Troy and Limantepe grew to a maximum extent of 9ha and 15 ha respectively in the late EBA, including their lower-town extensions (Massa, Şahoğlu 2015: fig. 9; Jablonka 2016: 64-69). The late EB II ('Copper Age') lower fortification at Alişar Höyük encircles a 11ha settlement (von der Osten 1937: fig. 103), while the EB III occupation of Beycesultan is estimated at ca 20ha (Abay 2011: 26). In Cappadocia, the spatial extent of Kültepe during the EB III period appears limited to the main mound at ca 21 ha (Makowski 2014: 94). These comparisons suggest that Eminler Höyük, Seyithan Höyük and Kanaç Höyük would have been among the largest EBA centres in western and central Anatolia (fig. 12). The increased site sizes further correspond with the expansion of settlement into marginal upland areas that were previously scarcely inhabited (see 'Inhabited landscapes', above). If our reconstruction of a $25 \mathrm{~km}$-long channel is correct (see 'Irrigated landscapes', above), this would also point toward a dramatic alteration of the local landscapes that required a significant degree of coordination and labour mobilisation. The possible introduction of irrigation would have been one element among a suite of innovations in EBA farming technology (Bachhuber 2015: 31-32, 130-38) that can begin to explain the dramatic demographic trends of this period. 


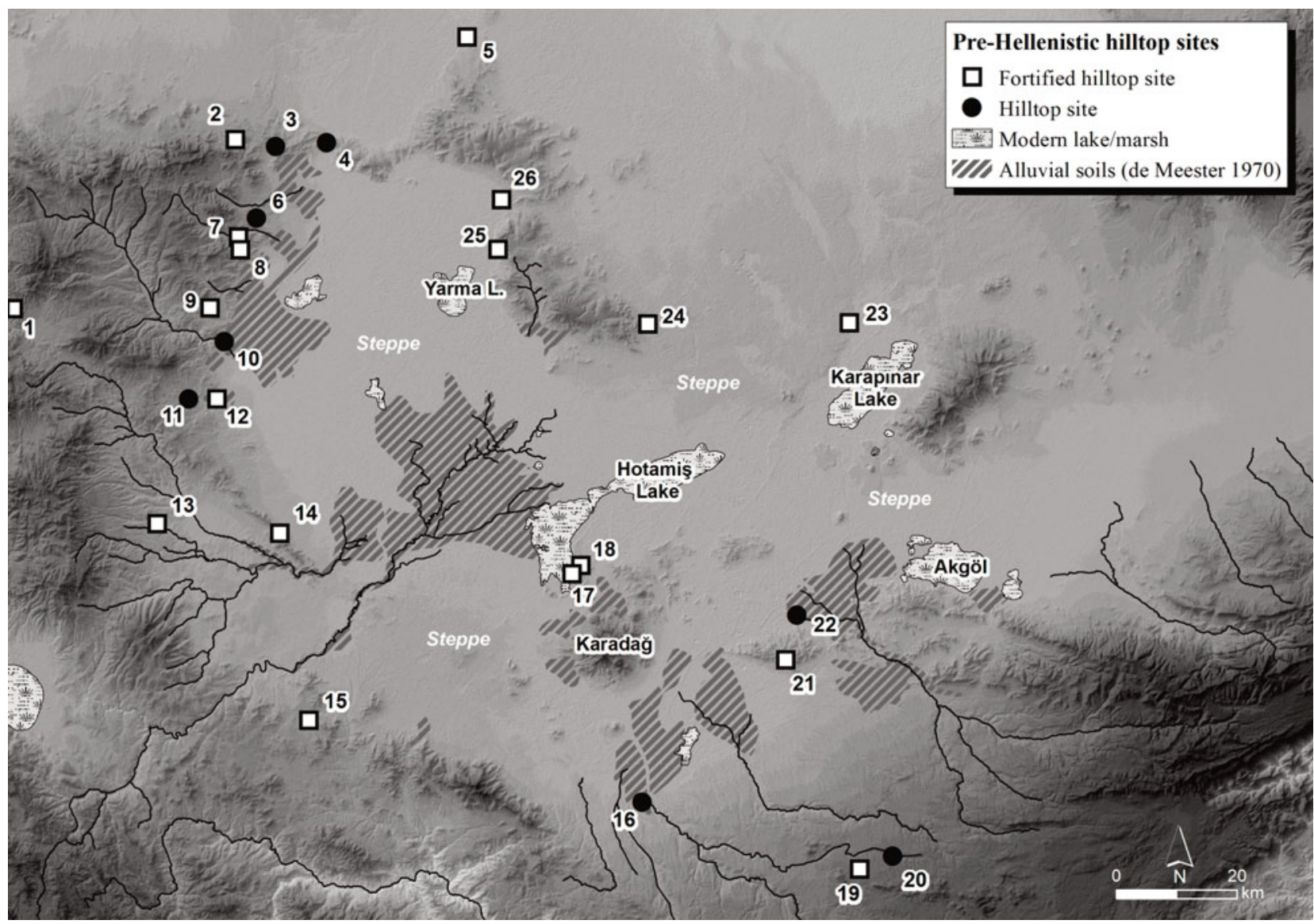

Fig. 11. Location of known pre-Hellenistic hilltop sites in the study region (for site numbers, see table 3) (map by M. Massa).

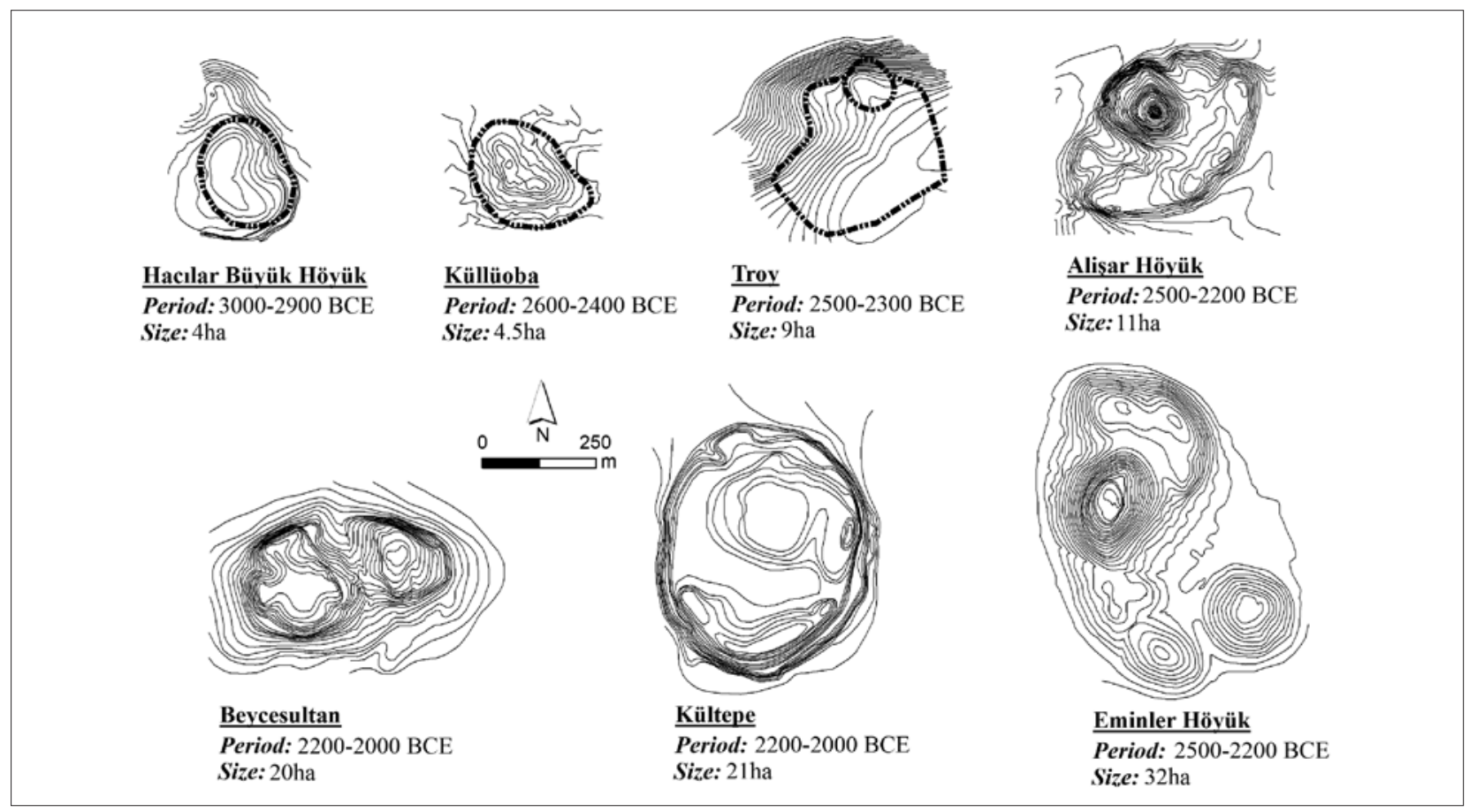

Fig. 12. Plans of the mounded formations of major EBA sites in western and central Anatolia, at the same scale. Note that, with the exception of Troy and Küllüoba, intensive survey targeting the lower settlement has not been conducted at these sites (based on Jablonka 2016: fig. 7; Efe et al. 2016: fig. 2; Kamış 2019a: fig. 4; Makowski 2014: fig. 2; Lloyd, Mellaart 1962: fig. 1; Umurtak, Duru 2014: fig. 2; von der Osten 1937: fig. 103; elaboration by M. Massa). 
Another aspect of region-wide coordination might also be glimpsed in the emergence of a clear settlement hierarchy in the early/mid-third millennium BCE, with secondary centres at around 15-25ha (table 2) and a lower tier of 2-7ha villages (Baird 1999: 14). Inter-site coordination is also apparent in the distribution of hilltop sites, at least in the area around modern Konya (see 'Defensive landscapes', above). While during the EBA the fortified hilltops appear confined to the Taurus piedmont, they suggest an emerging concern around security and control, and are broadly contemporary with a range of evidence across Anatolia for a surge in organised violence. On the Konya and Karaman plains, this is dramatically observed by a pattern first recognised in Mellaart's surveys in this area. Of 135 EBA sites identified, he records 35 as having evidence for destruction. These are all dateable to 'about $2300 \mathrm{BC}$ in rough terms' and most were subsequently abandoned (Mellaart 1963: 209-10, 236), a pattern confirmed by more recent surveys (Baird 2000: 15; Massa et al. 2019a: 165).

Mellaart famously attributed this horizon to an IndoEuropean invasion, for which, however, there is no archaeological evidence (Bachhuber 2013; Bachhuber, Massa 2016: 21). Conversely, this 'destruction horizon' is seemingly contemporary with similar phenomena across the Anatolian peninsula, with multiple proxies indicating a rise in social conflict, a drop in the number of sedentary settlements and the emergence of larger sites, particularly in central Anatolia (Massa 2014; Massa, Şahoğlu 2015: 69-72). The better-documented excavations reveal that the settlements that survived show heightened concerns around food security, as evidenced by larger storage facilities. The date of this horizon suggests a possible connection with the well-known $4.2 \mathrm{ka}$ BP drying event that affected societies across the Middle East between 2250 and 1900 cal. BCE (Weiss 2015). We tentatively suggest that the trends highlighted above might reflect a range of socio-economic and political responses to climatic and environmental stress (for example Wossink 2009; cf. Massa, Şahoğlu 2015 for the Anatolian context). Whatever the causes, the evident turmoil on the Konya-Karaman plains appears foundational to the emergence of the first territorial state entities in the early second millennium BCE.

\section{Early states in the Middle Bronze Age}

Following the destruction and reduction/abandonment of many of the largest EBA sites in the region, new centres emerged in the MBA, the best known of which is KonyaKarahöyük. Although very little has been published from the multi-decennial excavations, it is clear that between ca 1950 and 1750 BCE most of the main mound (ca 21ha in size) housed monumental buildings (Alp 1972: 11-13).
Investigations have also uncovered a thick fortification wall ca $100 \mathrm{~m}$ southwest of the mound that was associated with a gateway flanked by two towers (Alp 1959: 69192). The location of the wall and gate indicates the presence of an otherwise uninvestigated lower town, bringing the total occupied area to at least 35-40ha, and probably more (table 2). Furthermore, two archives of door-sealings (Alp 1972) reveal the existence of administrative practices focused on tracking the storage and redistribution of food and other commodities (Weingarten 1990; Massa, Tuna 2019: 69). In addition to KonyaKarahöyük, we identify other major centres (ca 25-30ha) at Türkmen-Karahöyük, Domuzboğazlayan Höyük, Büyük Aşlama Höyük and Sirçalı Höyük (table 2, fig. 4). Contemporary with these developments, numerous sites were resettled following the latest third-millennium abandonment (Massa et al. 2019b: 165-68). The major population centres continued to be confined to the major alluvial plains and we have observed no sedentary sites (tells) in the northern part of the Konya plain, which remained too dry for rain-fed farming. On the basis of the available data, it seems that during the MBA and LBA comparably sized settlement appears not to have formed on the Karaman plain, which generally remained less densely inhabited than in the preceding EBA (Kamış 2019b: 102-03).

The distribution of hilltop sites appears to encircle the whole of the Konya and Karaman plains (table 3, fig. 11), pointing to a coordinated effort to control access to the alluvial areas. We propose that the configuration of such sites may demonstrate a process of territorial formation that manifested in the formation of one or possibly more city-states. This hypothesis is corroborated by contemporary Assyrian tablets describing a constellation of numerous city-states across the Assyrian trade network, including several in or near the Konya plain (Palmisano 2018). City states were often in conflict with one another and many would have met their demise after only a few generations (Barjamovic et al. 2012: 43-52). This process seems not to have occurred in isolation, since MBA fortified sites are known in neighbouring areas as well, for example in Ilgın (Harmanşah, Johnson 2012) and Ereğli (Maner 2017).

The MBA pottery assemblages (fig. 5; see also Massa et al. 2019a: fig. 3; 2019b: fig. 10) reveal the introduction of innovative forms and surface treatments which, in the latest phase of the EBA, had begun to appear across central Anatolia (see Efe, Türkteki 2005; Şahin 2015). Major sites like Büyük Aşlama Höyük, Domuzboğazlayan Höyük, Sırçalı Höyük, Türkmen-Karahöyük (Osborne et al. 2020, this volume: figs 9.8, 10) and Konya-Karahöyük (Alp 1972: fig. 8.16) have yielded high-quality ceramic materials that are directly comparable with examples from 
Kültepe, Acemhöyük, Alişar Höyük, Boğazköy and Ovaören (Orthman 1963; Emre 1964; Aydın 2015) and which might be considered imports. Glyptic styles show a similar connectivity with the east. Although the KonyaKarahöyük sealings mostly show a use of stamps with zoomorphic or geometric patterns that can be considered 'Anatolian', some have been impressed by Assyrian or Assyrianising cylinder seals with anthropomorphic scenes (Alp 1972) that reveal contacts with the Old Assyrian trade network.

The relationship between the Konya plain and the Old Assyrian trade network continues to be a matter of debate, with most scholars arguing for a marginal status of this region within the network (recently, Barjamovic 2019). However, several toponyms mentioned in the Kültepe texts, including Purušhaddum (a kārum), Ušša (a wabartum) and Hudurut, are recorded together in the same itineraries and can be safely located at the western end of Assyrian commercial relations (Barjamovic 2011: 335-36, with references). The possibility that this western terminus included the Konya plain is supported by later Hittite texts. These record Purušhaddum (as Paršuhanda), Ušša and Ikkuwaniya in geographical association with the Hulaya River Land (Hoffman 1984: 42, CTH 19, iii 37; Singer 1996: 16, CTH 381, ii 37), widely accepted to encompass the region around the Çarşamba river and its delta (Garstang 1944: 14-37; cf. recently Forlanini 2017: 243). While such identifications are by no means conclusive, they warrant further consideration of the location of the Konya region within the Assyrian trade network.

\section{Hittite control}

Like elsewhere in central Anatolia, the transition from the MBA (historically marked by the termination of the Assyrian trading enclaves) to the early LBA (LBA I, historically marked by the formation of the Land of Hatti) is at best murky for the Konya-Karaman plains. From an archaeological perspective, the major centres show considerable stability of occupation (table 2; also Glatz 2009: fig. 5), with the single exception of KonyaKarahöyük, whose size shrinks after its destruction (cf. Güneri 2013 for the existence of a - poorly documented - LBA occupation of the site). While acknowledging the difficulty of distinguishing MBA from LBA materials in non-elite contexts, the materials retrieved from the fortified hilltops also suggest continuity in the maintenance of a region-wide defensive network (table 3, fig. 9). Similarly, our preliminary analysis of regional pottery assemblages reveals a high degree of material-culture continuity in terms of shapes, wares and manufacturing traditions, also seen elsewhere in central Anatolia (cf. Schoop 2011). For the Konya-Karaman plains, we suggest that this perceived continuity may also have been related to the low degree of Hittite intervention in this region during the Old Kingdom. While military campaigns against centres located on the Konya plain or in its vicinity (for example against Ušša) are mentioned already for the reigns of Labarna and Hattusili I (ca 1650 BCE; Forlanini 2017: 242-43), it is only for the reign of Telipinu (ca 1500 $\mathrm{BCE}$ ) that there is textual evidence of a more stable Hittite presence in the region (Hoffmann 1984: 42-43). However, up until ca $1400 \mathrm{BCE}$, Hittite rule in the area would have been based on a constellation of town-based units headed by local administrators and thus characterised by relatively minimal administrative integration (Matessi 2016: 1401-41).

More significant changes in material culture can be detected for the 14th and 13th centuries BCE (LBA II), roughly contemporary with the creation of the Lower Land, a directly administered Hittite province that likely included the Konya, Karaman and Ilgin plains as well as parts of the Lakes District (Matessi 2016: 134-37; Forlanini 2017: 239-40). This increased Hittite political investment may have resulted in shifts in the hierarchical organisation of settlements and determined the creation of new administrative centres within the Lower Land (Matessi 2016: 143). The growth of Türkmen-Karahöyük from a 30 ha settlement to a large urban site up to ca 125 ha in size during this phase (see Osborne et al. 2020, this volume) suggests that the site could have fulfilled this role. This hypothesis is further corroborated by the appearance at the site of several 'Northern-Central Anatolian (NCA)style' ceramic forms (sensu Glatz 2009), Eggshell Ware and Drab Ware that reflect a more direct connection with the Hittite heartland (Osborne et al. 2020, this volume: figs $11,12.1-4)$. A limited range of such forms has been identified only at major centres on the Konya plain (fig. 6.14), as well as at Porsuk and Kilisetepe (Matessi, Tommasini Pieri 2017: 100-01).

In the early 13 th century BCE, Muwatalli II moved the Hittite capital from Hattuša to Tarhuntašša, a city situated in the Lower Land (CTH 81; Forlanini 2017; Matessi, Tommasini Pierie 2017, with literature). His decision has often been explained as one aspect of the king's religious reforms (resembling Akhenaton's move to El-Amarna; see Singer 2006; d'Alfonso 2014). Yet, from a politicalgeographic perspective, the move can also be explained by the need for a more central and better-connected location from which to govern the empire (Matessi 2016: 146-47; Forlanini 2017: 251). Tarhuntašša would also have been much closer than Hattuša to the Aegean-Levantine maritime networks, closer to troublesome polities in the west (for example Arzawa) and closer to annexed Hittite provinces in the northern Levant (Forlanini 2017: 250-51). Subsequent subordination treaties signed between Hattuša and Tarhuntašša in the mid-13th century BCE (CTH 106.1, 
106.2) reveal that Tarhuntašša had been an appanage state formally subject to Hatti but eventually competing with it. This situation lasted until the collapse of the Hittite Empire under Šuppiluliuma II (ca 1180 BCE; Otten 1988; Gurney 1993; Hawkins 1995; van den Hout 1995). By combining topographic, text-based and archaeological considerations, the following analysis approximates the boundaries of the territory of Tarhuntašša, and introduces a new hypothesis for the identification of its capital.

\section{Revisiting the identification of Tarhuntašša}

Our understanding of the extent of the kingdom of Tarhuntašša derives from the subordination treaties cited above between Hattusili III/Tudhalya IV and KuruntaUlmi Teššub (CTH 106.1, 106.2; Otten 1988; van den Hout 1995). Currently, there is no evidence that a kingdom of Tarhuntašša existed before Hattusili III and Kurunta (Forlanini 2017: 245). Earlier scholarship hypothesised that the Hulaya River Land (i.e. the territory around the Çarşamba river delta) would have been a later addition to the kingdom, extending from its core in the Taurus mountains (for example Hawkins 1995; also Dinçol et al. 2000; Bahar 2005). However, there are reasons to doubt such a scenario. First, at least three treaties are known to have been written, although the two cited above are the only extant copies, and each is a revised version of the previous (van den Hout 1995). Updates include changes in the location of borders between Hatti and Tarhuntašša, which are always written with the formula 'Previously, in the direction of $\mathrm{x}$, the frontier was at $\mathrm{y}$; now, I have (re)established the frontier at z' (Beckman 1996: 102-18). In neither of the preserved treaties is there any indication that the Hulaya River Land was added to the territory of Tarhuntašša at a later stage. There is therefore good reason to argue that the kingdom of Tarhuntašša included the Hulaya River Land from its beginning.

Second, the passages describing the borders always describe the Land of Hatti in opposition to the Hulaya River Land, rather than in opposition to the Land of Tarhuntašša. This strongly indicates that the frontiers of the Hulaya River Land coincided with the frontiers of the Land of Tarhuntašša, and thus the Hulaya River Land largely equates with the territory of Tarhuntašša (Forlanini 2017: 246). Lastly, the discovery of a Luwian-inscribed rock monument at Hatip (south of Konya), commissioned by Kurunta, confirms this polity to have included at least parts of the Konya plain (Bahar 1998; recently Harmanşah 2017: 41).

Based on the description of borders within the treaties, the kingdom of Tarhuntašša would have included the Konya and Karaman plains, as well as the Beyşehir and Seydişehir plains to the west and a stretch of the Mediterranean coast (recently, Melchert 2007; d'Alfonso 2014;
Forlanini 2017; Erbil, Mouton 2018). The Göksu valley, with the Hittite outpost at Kilisetepe, would have been another important corridor to the Mediterranean via the harbour at Ura (outside of Tarhuntašša's territory; Matessi, Tomassini Pieri 2017: 99).

In light of this reasoning, we suggest that the kingdom's political centre would have been located on the fertile and densely populated Konya and Karaman plains, which were also encircled by a defensive network of fortified hilltops (see 'Defensive landscapes', above). Conversely, the Taurus mountains would have been marginal in the Tarhuntašša polity. We put forward this reconstruction based on the following observations.

(1) The Konya-Karaman plains include some of the largest Bronze Age settlements in central and western Anatolia (see 'Inhabited landscapes', above), but the highlands were scarcely inhabited. Where sedentary settlements have been identified (in intermontane valleys), they were generally small and never above 8 ha.

(2) The ecology of the Taurus mountains (up to 2,500m above sea level) could not have sustained large urban populations, and settling a capital and secondary/ dependent centres in this landscape would have required complex or impractical logistics. Furthermore, movement across the Taurus mountains and networks of communication more broadly would have been disrupted during the winter months. This strongly suggests that territories in and south of the Taurus mountains would have been challenging to control militarily and administratively beyond the major valleys.

In addition, while attempting to draw the kingdom's political boundaries, we argue that these would have tended to follow natural landscape features wherever possible. Mountain ranges, lakes and large rivers would have been easily recognisable markers (for example to agree upon in a treaty; Erbil, Mouton 2018: 75-79) and they would also have served as barriers to movement (for example of armies). There are historical parallels for persistent cultural and political frontiers along topographic/ecological fault lines in Anatolia (Massa 2016: 249-53; contributions in Baysal, Karakatsanis 2017), which support the likelihood of similar frontiers having existed around the KonyaKaraman plains.

We suggest therefore that in the mid-13th century BCE the kingdom of Tarhuntašša would have extended across most of the Konya-Karaman plains (fig. 13). The strategically important Göksu valley and the fertile Beyşehir/Seydişehir plains would have constituted two additional components of the polity. Beyond this region, the coastal strip between Parha and Šaruwanda would have been difficult to control directly and might have been linked to the kingdom by looser political ties. The Taurus mountains were likely outside effective administrative and 


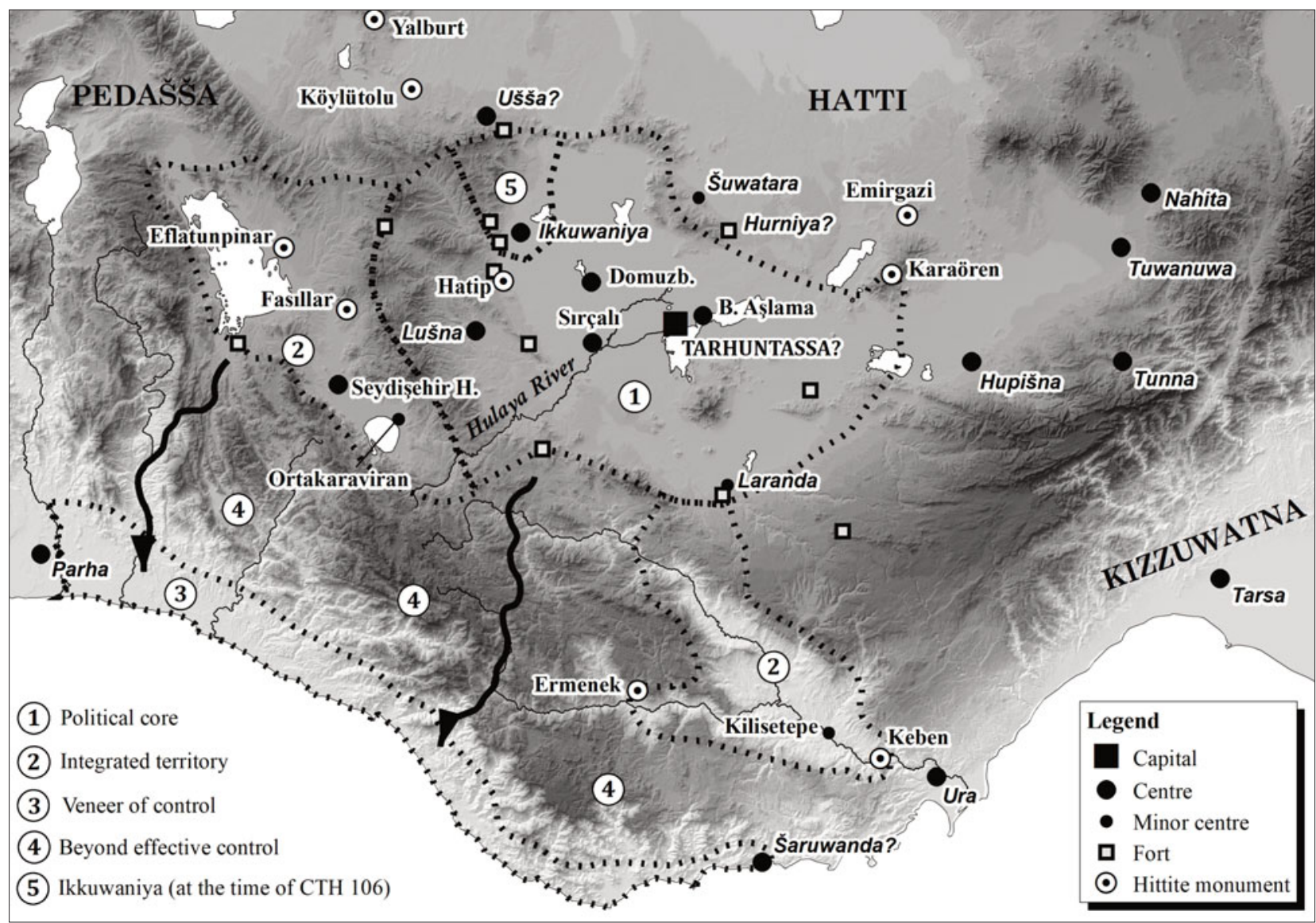

Fig. 13. Suggested extent of the kingdom of Tarhuntašša in the mid-13th century BCE. Black arrows indicate the two major modern routes connecting the central plateau with the Mediterranean coast (map by M. Massa).

military control. Lastly, the kingdom existed at least until the collapse of the Hittite Empire around $1180 \mathrm{BCE}$ (Hawkins 1995), and it is possible that, in one form or another, it continued to exist even into the eighth century BCE (see below). We therefore should imagine that Tarhuntašša's boundaries likely changed considerably over time.

When considering the location of the city of Tarhuntašša, we should be looking for a large settlement within the borders reconstructed above. The size of this city should reflect its administrative and political importance. Even if its role as a Hittite capital was short-lived, Tarhuntašša continued to be the capital of a kingdom at least for three generations after the royal court was transferred back to Hattuša. Several hypotheses have been put forward for the location of the city of Tarhuntašša, including Meydancık Kalesi, Dalysandos, Kilisetepe, Zoldura Höyük, Hamza Zındanı Höyük, Karaman Kale Höyük, Hatip Höyük, Sirkeli Höyük and Kızıldağ (see Jones 2019: 48-61, with literature). So far, none of these potential candidates has revealed credible evidence for the site being a major Hittite centre, either due to its remote location, its small size, the lack of archaeological indica- tors of a clear Hittite presence or some combination of these factors. The hilltop site of Kızıldağ is favoured by many (for example Dinçol et al. 2000; Singer 2006; Melchert 2007). However, despite its elaborate ritual apparatus (now to be redated to the MIA; Goedegebuure et al. 2020, this volume), there is no evidence of a lower settlement beyond the fortified hillock itself, which barely encloses 1.5 ha (table 3 ) and would hardly have accommodated any monumental architecture worthy of a capital (for similar views, see d'Alfonso 2014).

As an alternative, we suggest that the regional centre of Türkmen-Karahöyük in the eastern Çarşamba river delta is a good candidate for the following reasons. The settlement comprises a $30 \mathrm{ha}, 35 \mathrm{~m}$-high mound that could have accommodated a large monumental space (Massa et al. 2019b: 168). The settlement quadrupled in size from $30 \mathrm{ha}$ in the MBA to up to 125 ha during the LBA (Osborne et al. 2020 , this volume). It is the only LBA site in central Anatolia whose size remotely compares with Hattuša (at 180ha; Glatz 2009: 132-33; Mielke 2011: 183-84). Its pottery assemblages show the presence of high-quality eggshell and NCA-style ceramics which, outside the Hatti heartland, are generally associated with Hittite administra- 
tive centres. It is centrally located within the Hulaya River Land, a large agricultural basin that could have supported a significant urban population. It was less exposed to attacks from western adversaries (for example Arzawa) than other sites on the Beyşehir/Seydişehir plains and more central to the Hittite Empire. The site continued to be one of the most important centres in the region at least until the eighth century BCE, when it was the capital of Hartapu, a Middle Iron Age ruler (Osborne et al. 2020, this volume; and see below). Hartapu's title of 'Great King' and his father's throne name 'Mursili' are a direct reference to the Hittite rulers and suggest a real or imagined claim of dynastic continuity with Kurunta.

Two potential objections might be raised against the hypothesis that Türkmen-Karahöyük is to be equated with the city of Tarhuntašša. Some have argued that the establishment of a new Hittite capital would have followed conventions established with the founding of the original Hittite capital at Hattuša, including a new location on a prominent topographic position (a mountain city) and related stone-masonry construction traditions, rather than on a pre-existing settlement mound with mudbrick construction (for example Masson 1995; Singer 2006). Yet, numerous Hittite centres, including Uşaklı Höyük, Alişar Höyük, Alaca Höyük, Kayalıpınar and Ortaköy, do not conform to these expectations; they were built upon pre-existing settlement mounds and/or located on alluvial plains (Mielke 2011). In fact, even Hattuša was established on an already existing settlement (Schachner 2017). Others have emphasised that Tarhuntašša is not mentioned in earlier Old Assyrian or Hittite texts, and therefore could not have existed before Muwatalli II (for example Singer 2006: 42). Following Massimo Forlanini (2017: 245), we argue, however, that an already existing centre might well have been renamed Tarhuntašša (literally the city of the Storm-God Tarhunta) within the context of Muwatalli's religious reforms. If this were the case, the original name would need to be sought in one of the centres recorded in the Old Assyrian and Hittite texts.

\section{A Middle Iron Age kingdom}

The period between the collapse of the Hittite Empire (ca $1180 \mathrm{BCE}$ ) and the emergence of the so-called Neo-Hittite kingdoms in the ninth century $\mathrm{BCE}$ is one of the least understood and most discussed periods of central Anatolia (Bryce 2012; Osborne forthcoming). At all the best-documented sites in the northern section of the plateau (including Hattuša, Gordion and Kaman Kalehöyük) there seems to have been a total change in material culture, architecture and socio-economic structures more broadly (Matsumura 2008; Seeher 2010; Kealhofer et al. 2019). The transition at these sites included the demise of urban life and the disappearance of writing, centralised adminis- tration, monumental architecture and mass-produced (wheelmade) pottery (Summers 2017).

Since we are lacking a refined stratigraphic sequence for the Konya-Karaman plains, it is difficult currently to distinguish between EIA and MIA materials beyond a limited number of painted ceramic markers. Nevertheless, both the assessment of KRASP's regional pottery assemblages and the detailed analysis carried out at TürkmenKarahöyük, based closely on the stratigraphic sequences of Kınık Höyük and Ovaören in Cappadocia (Ergürer 2016; Şenyurt et al. 2019), indicate a higher degree of continuity than the area to the north. This continuity has recently been observed also at Kınık Höyük, where large storage facilities dateable to the tenth century cal. BCE suggest a continuation of urbanising administrative practices (Castellano 2018) and the fortification system around the citadel remained in use throughout the 11th to ninth century BCE (Matessi et al. 2019: 132-33). In southern Cappadocia, continuity between the LBA and EIA is further detectable in the regional settlement patterns (Matessi et al. 2019: 122).

In contrast with sites further north, our preliminary ceramic analysis of the Iron Age assemblages from more than 100 sites on the Konya-Karaman plains suggests that there was no major handmade pottery tradition in the late second to early first millennium BCE. Tentatively, this evidence points to a continuity in the modes and socio-economic contexts of ceramic production. In addition, a significant degree of continuity is suggested by similarities between LBA and Iron Age fabrics and shapes. At the regional level, one of the most common LBA wares (Buff Ware) became the most widespread Iron Age production (Common Ware), and a significant proportion of table, storage and cooking shapes also gradually evolved into the Iron Age (for example figs 6.17-18, 23-24).

Investigations at Türkmen-Karahöyük also support this continuity. For instance, results from the 2019 intensive survey demonstrate that the settlement maintained approximately the same size between the LBA and the EIA/MIA (100-125ha; Osborne et al. 2020, this volume). Even without a detailed understanding of the settlement layout, size alone suggests the persistence of the urban character of the settlement. A newly discovered eight-century BCE Hieroglyphic Luwian inscription at the site (TÜRKMENKARAHÖYÜK 1; Goedegebuure et al. 2020, this volume) corroborates this hypothesis. In this and other inscriptions associated with Hartapu (cf. Hawkins 2000: 433-42), both the title 'Great King' used by Hartapu and the throne name of his father, Mursili, are direct references to the Hittite royal dynasty. They each reveal a real or imagined claim of continuity between the rulers of the LBA kingdom of Tarhuntašša and those of the MIA kingdom centred at Türkmen-Karahöyük. 
Alongside evidence for continuity, we also observe significant changes in regional sociopolitical structuring. During the EIA/MIA, several major LBA sites (including Domuzboğazlayan and Büyük Aşlama) were reduced in size or abandoned. Conversely, our preliminary analysis of ceramic assemblages suggests that, together with Türkmen-Karahöyük, Alaattin Tepe and Zoldura/Lystra rose to the status of important centres, as also observed by the presence of the so-called Alişar IV wares (Bahar 1999a: 20-21, 29-30) which are otherwise rare in the region. The second major change can be observed in the defensive network of fortified hilltops, which appears to contract during the EIA/MIA periods before expanding again in the LIA (table 3). Also, Seçme Kale, by far the largest fort in this period with a MIA construction very similar to Yaraşl1-Çevre Kale (fig. 10b; Özgüner, Summers 2017), is located at the western end of the Konya plain rather than in the east (i.e. closer to the Tabalian kingdoms) where one would have expected more concerns around security. This pattern is puzzling, because there should be a more extensive and coordinated fortification system contemporary with the apogee of Türkmen-Karahöyük during the MIA.
At this stage, we are struggling to understand the geopolitical relationship between the polity at TürkmenKarahöyük during the MIA and its neighbours. Nevertheless, the corpus of Hieroglyphic Luwian inscriptions from the region may complement archaeological evidence from the Konya and Karaman plains. The new inscription of TÜRKMEN-KARAHÖYÜK 1 refers to a conflict with 13 kings (Goedegebuure et al. 2020, this volume). Similar references to the existence of numerous local rulers in Assyrian sources, as well as in the TOPADA rock inscription by the Tabalian king Wassusarma, suggest a political landscape of multiple, territorially fluid kingdoms whose alliances and borders were constantly shifting (see d'Alfonso 2019). The peak of inscriptions, generally dated to the eighth century BCE, provides evidence for three primary spheres of influence during this time. One kingdom must have been based on the Konya plain and ruled by the Mursili/Hartapu dynasty, another was based at Tuwanuwa and ruled by the Saruwanis/Muwaharanis I/Warpalawas/Muwaharanis II dynasty and the last was centred on Kayseri and ruled by the Tuwati I/Tuwati II/Wasusarma dynasty (fig. 14; see also Akçay 2014; Weeden 2017; Şenyurt, Akçay 2018). If this reconstruction

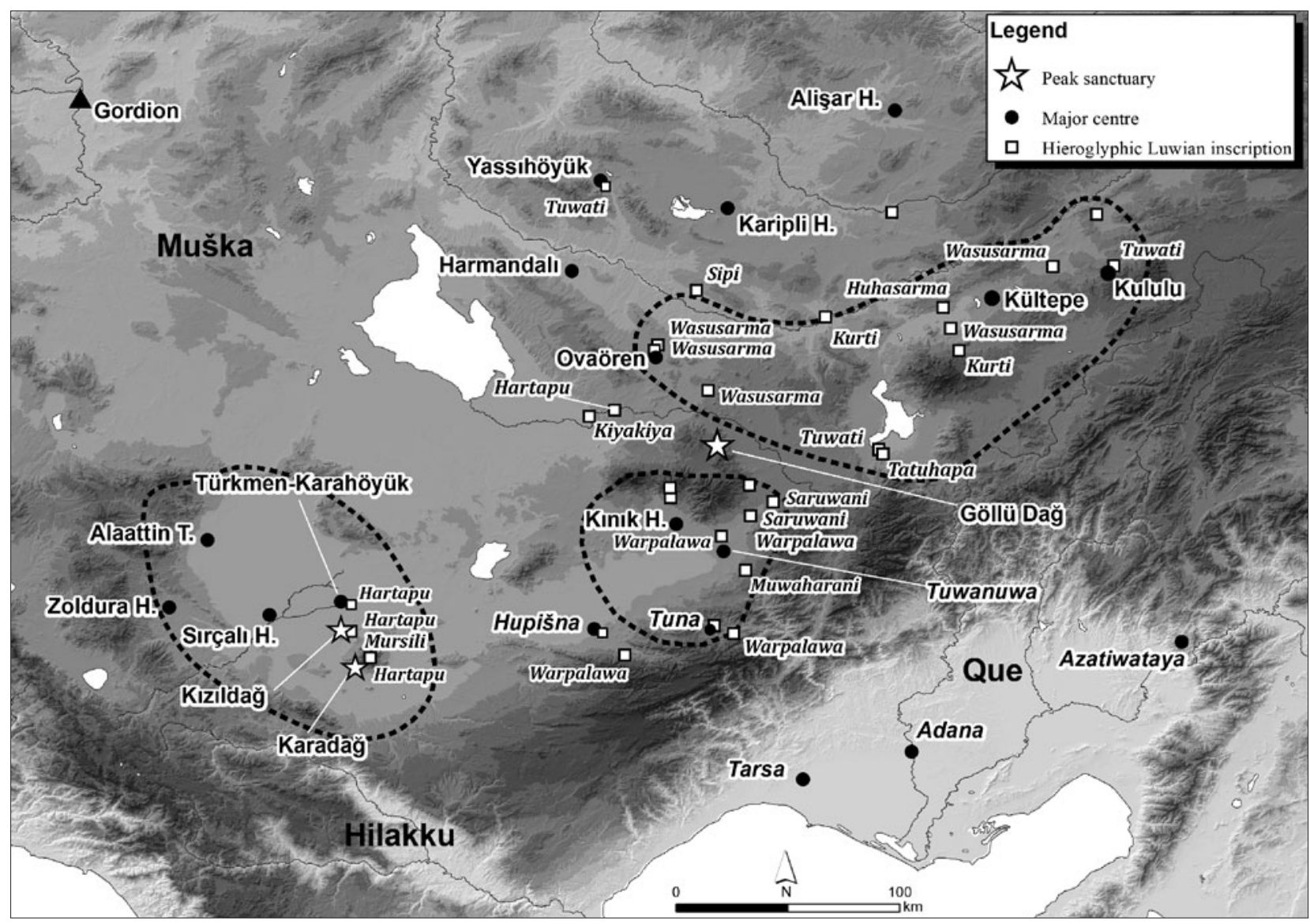

Fig. 14. Suggested spheres of influence of the main Middle Iron Age kingdoms during the ninth to eighth century BCE, together with the locations of major centres and known Iron Age Hieroglyphic Luwian inscriptions (map by M. Massa). 
is correct, then the BURUNKAYA inscription by Hartapu, just $34 \mathrm{~km}$ southwest of TOPADA (Hawkins 2000: $437-$ 38, 451-61), could locate the furthest extent of a military campaign of Hartapu or the easternmost boundary of his expanded kingdom.

\section{The Late Iron Age and Achaemenid conquest}

For the LIA we have identified a number of trends that we suggest relate to the onset of Achaemenid hegemony in this region. On the one hand, there was a significant change in how settlements were internally structured, and the prehistoric/early historic agglutinated architecture that produced the typical mound formation gave way to a more dispersed layout generally outside the earlier tell (see 'Inhabited landscapes', above). In addition, during this period we can observe the emergence of numerous (albeit relatively small) sedentary sites in the northern part of the Konya plain, an area previously largely uninhabited. This pattern is possibly the result of a coordinated programme of irrigation on the steppe during the LIA (see 'Irrigated landscapes', above), and we suspect these trends may be related to major socio-economic changes in the region. The shift from nucleated villages to dispersed farmsteads and hamlets suggests both a diminished preoccupation with defensibility within the integrated context of an empire and a more efficient exploitation of agricultural land. Similar patterns of exploitation and reorganisation are visible around Gordion, albeit with an emphasis on animal husbandry rather than agricultural production (Dusinberre 2019: 120-21). Palaeobotanical analysis at Kınık Höyük also reveals the sudden intensification of agricultural production during the sixth century $\mathrm{BCE}$, contemporary with Achaemenid influence in Cappadocia (Lorenzo d'Alfonso, personal communication October 2019).

We also observe a similarly high level of coordination in the network of fortified hilltops that encircles the Konya and Karaman plains, including a functional hierarchy with very large and architecturally sophisticated fortresses at the top and small watchtowers at the bottom that are dateable to the LIA by surface pottery. Equally complex and contemporary networks of fortifications have been observed in several regions across western Anatolia and the Black Sea region (Khatchadourian 2012: 968). Rather than simply protecting the region from external threats, we suggest such regional defensive systems served more varied purposes in the Achaemenid Empire. These include exerting administrative control (i.e. to exact taxation), regulating commerce within the imperial territory and safeguarding storage facilities (Khatchadourian 2012: 968), in addition to the more military function of controlling social unrest (see Dusinberre 2013: 94-113).

\section{Conclusions}

This paper has shown that the integration of data and methods from archaeological surveys, computational archaeology, palaeoenvironmental research and text-based studies can be very effective in understanding sociopolitical processes in protohistoric and early historic southcentral Anatolia. It has also promoted a longue durée perspective on changes to the regional socio-ecological systems, bridging the studies of archaeological phases that are generally investigated in isolation and therefore facilitating a better understanding of the processes of urbanisation and state formation.

By prioritising the archaeology of the Bronze and Iron Ages of the Konya and Karaman plains we have developed both a counterpart and complement to the much better investigated Neolithic and Early Chalcolithic periods. The analytical results presented here support the claim that this basin is of fundamental importance to understanding the transition from village-based societies to territorial states in western and central Anatolia, and that it warrants much more scientific research than it has attracted so far. For instance, our data for the region push back the onset of political integration and territorial formation in central/western Anatolia to the mid- to late third millennium BCE. They also suggest that the type of city-state that is documented for the Assyrian trade network likely also existed on the Konya-Karaman plains in the early second millennium BCE. Through a detailed assessment of archaeological, environmental and philological evidence, we have provided a much more detailed and analytically comprehensive assessment of the location of the city of Tarhuntašša and its territory. While our hypothesis for the location of Tarḩuntašša at TürkmenKarahöyük is by no means conclusive, we argue that this site needs to be considered in any future assessments of this particular historical geography. Furthermore, the results of KRASP and TISP provide compelling evidence for the existence of a previously unknown MIA kingdom, whose capital was very likely located at TürkmenKarahöyük. Lastly, the regional analysis of the LIA shows significant changes in land-use and settlement that, we argue, are closely linked with Achaemenid hegemony in the region.

In conclusion, we hope this work can provoke a more sustained discussion on how to frame the analysis of social complexity in Anatolia, a region between two major poles of research (the Aegean and Mesopotamia) with different methodological and theoretical orientations. While we have drawn generously from the research traditions of both poles, we have developed an approach that we believe is appropriate for and specific to the scale of these developments in central Anatolia. For us, this study has been an important platform to raise possibilities for future research 
and test hypotheses that will need to be developed further. We hope that the continuation of KRASP will soon provide a more fine-grained analysis to confirm, improve or refute any number of our assertions.

\section{Acknowledgements}

We would like to thank Atakan Akçay, Gojko Barjamovic, Lorenzo d'Alfonso, Massimo Forlanini, Marie-Henriette Gates, Yalçın Kamış, Alvise Matessi, Yücel Şenyurt and Geoffrey Summers for their discussions, comments and critiques on early drafts that much improved the quality of this paper. They do not necessarily share all the views presented here. In addition, we would like to extend our gratitude to Fadime Arslan, Ebru İncaman, Su Ün (for the drawings), Osman Dengiz (for drawing digitisation and drone imagery) and the KRASP 2017-2019 and TISP 2019 teams, without whom this work would not have been possible. Special thanks are offered to Aliye Usta (Turkish Ministry of Culture and Tourism) for her immense help in advising on bureaucratic aspects of the project and Muzaffer Saçkesen (the 2019 Ministry representative) for his kindness, friendliness and help in relating with the people of the Konya plain. Finally, we are grateful to the sponsors of the 2019 KRASP season: the British Institute at Ankara, the Luwian Studies Foundation, the Gerald Averay Wainwright Fund (University of Oxford) and Çukurova University.

\section{Bibliography}

Abay, E. 2011: 'Preliminary report on the survey project of Çivril, Baklan and Çal plains in the Upper Meander basin, southwest Anatolia' Ancient Near Eastern Studies 48: 1-87

Akçay, A. 2014: 'Tabal ülkesinin tarihsel süreci üzerine bir değerlendirme' Tarih Incelemeleri Dergisi 29.1: 37-58. https://doi.org/10.18513/egetid.69160

Alp, S. 1959: 'Karahöyük kazısı' Belleten 23.92: 691-92

- 1972: Konya Civarında Karahöyük Kazılarında Bulunan Silindir ve Damga Mühürleri. Ankara, Türk Tarih Kurumu Basımevi

Ayala, G., Wainwright, J., Walker Hodara, R., Lloyd, J.M., Leng, M.J., Doherty, C. 2017: 'Palaeoenvironmental reconstruction of the alluvial landscape of Neolithic Çatalhöyük, central southern Turkey: the implications for early agriculture and responses to environmental change' Journal of Archaeological Science 87: 30-43. https://doi.org/10.1016/j.jas.2017.09.002

Aydın, A. 2015: Ovaören 2012 Kazı Sezonu Orta Tunç Çă̆ı Seramik Buluntuları. MA thesis, Gazi University

Bachhuber, C. 2013: 'James Mellaart and the Luwians: a culture-(pre)history', in A. Mouton, I. Rutherford, I. Yakubovich (eds), Luwian Identities: Culture, Language and Religion between Anatolia and the Aegean. Leiden, Brill: $279-304$. https://doi.org/10.1163/9789004253414_014

- 2015: Citadel and Cemetery in Early Bronze Age Anatolia. London, Equinox

- forthcoming: 'Deliberating damage to archaeological landscapes in the Konya plain in central Turkey', in C. Greco, P. Del Vesco (eds), Statues Also Die: Destruction and Preservation in Ancient and Modern Times. Torino, Museo Egizio

Bachhuber, C., Massa, M. 2016: 'Engaging the material and academic legacies of the first BIAA-led surveys in the Konya plain' Heritage Turkey 6: 21-22. https://doi.org/10.18866/biaa2016.029

Bahar, H. 1997: 'Doğanhisar, Ilgın, Kadınhanı ve Sarayönü yüzey araştırmaları 1995' Araştırma Sonuçları Toplantısı 14.2: $359-74$

- 1998: 'Konya araştırmaları III: Lykaonia (Konya merkez bölgesi)' Selçuk Üniversitesi Edebiyat Fakültesi Dergisi 12: 197-206. https://dergipark.org.tr/en/pub/sefad/issue/16458

- 1999a: Demir Çă̆ı'nda Konya ve Çevresi. Konya, Selçuk Üniversitesi Yayınları

- 1999b: 'Konya ve Çevresi yüzey araştirmaları 1997' Araştırma Sonuçları Toplantısı 16.2: 23-54

— 2001: ‘1998-1999 yılı Konya-Karaman illeri yüzey araştırmaları’ Araştırma Sonuçları Toplantısı 18.2: 187-204

- 2002: ‘Konya ve Karaman illeri yüzey araştırmaları 2000’ Araştırma Sonuçları Toplantısı 19: 257-70

- 2004: 'Konya-Karaman bölgesi yüzey araştirmaları 2002' Araştırma Sonuçları Toplantısı 21.1: 203-16

- 2005: 'Tarhuntašša araştırmaları 1994-2002' in A. Süel (ed), V. Uluslararası Hititoloji Kongresi bildirileri: Çorum, 02-08 Eyluil 2002. Ankara, Çorum İl Özel İdaresi: 83-117

- 2008: 'Konya - Karaman yüzey araştırmaları 2006' Araştırma Sonuçları Toplantısı 25.1: 235-54

- 2009: 'Konya ve Karaman illeri ve ilçeleri 2007 yılı arkeolojik yüzey araşıirması' Araştırma Sonuçları Toplantısı 26.1: 117-34

- 2010: 'Konya ve Karaman illeri ve ilçelerinde arkeolojik yüzey araştırması, 2008' Araştırma Sonuçları Toplantısı 27.3: 415-33

— 2011: 'Konya ve Karaman illeri ve ilçeleri yüzey araştırması 2009' Araştırma Sonuçları Toplantısı 28.2: 303-19 
Bahar, H., Koçak, Ö. 2004: Eskiçă̆ Konya Araştırmaları 2 (Neolitik Çăğdan Roma Dönemi Sonuna Kadar). Konya, Kömen

Baird, D. 1999: 'Konya Plain Survey, central Anatolia' Anatolian Archaeology 5: 13-14

- 2000: 'Konya Plain Survey' Anatolian Archaeology 6: 15

— 2006: 'The history of settlement and social landscapes in the early Holocene in the Çatalhöyük area' in I. Hodder (ed), Çatalhöyük Perspectives: Reports from the 1995-99 Seasons. London/Cambridge, British Institute at Ankara/McDonald Institute for Archaeological Research: 55-74

Baird, D., Fairbairn, A., Jenkins, E., Martin, L., Middleton, C., Pearson, J., Asouti, E., Edwards, Y., Kabukçu, C., Mustafaoğlu, G., Russell, N., Bar-Yosef, O., Jacobsen, G., Wu, X., Baker, A., Elliott, S. 2018: 'Agricultural origins on the Anatolian plateau' Proceedings of the National Academy of Sciences 115.14: $3077-86$. https://doi.org/10.1073/pnas.1800163115

Barjamovic, G. 2011: A Historical Geography of Anatolia in the Old Assyrian Colony Period. Copenhagen, University of Copenhagen/Museum Tusculanum Press

- 2019: 'Silver, markets and long-distance trade in the Konya region, 2400-1700 BCE' in Ç. Maner (ed), Crossroads: Konya Plain from Prehistory to Byzantine Period: 9th International ANAMED Annual Symposium. Istanbul, Ege Yayınlar1: 71-82

Barjamovic, G., Hertel, T., Larsen, M.T. 2012: Ups and Downs at Kanesh. Leiden, Nederlands Instituut voor het Nabije Oosten

Baysal, E., Karakatsanis, L. (eds) 2017: Bordered Places, Bounded Times: Cross-Disciplinary Perspectives on Turkey. London, British Institute at Ankara. https://www.jstor.org/stable/10.18866/j.ctt1n7qk1h

Beckman, G. 1996: Hittite Diplomatic Texts. Atlanta, Scholars Press

Bevan, A., Conolly, J. 2013: Mediterranean Islands, Fragile Communities and Persistent Landscapes: Antikythera in Long-term Perspective. Cambridge, Cambridge University Press. https://doi.org/10.1017/cbo9781139519748

Bottema, S., Woldring, H. 1984: 'Late Quaternary vegetation and climate of south-western Turkey part II' Palaeohistoria 26: 123-49

Boyer, P., Roberts, N., Baird, D. 2006: 'Holocene environment and settlement on the Çarsamba alluvial fan, southcentral Turkey: integrating geoarchaeology and archaeological field survey’ Geoarchaeology 21.7: 675-98. https://doi.org/10.1002/gea.20133

Bryce, T. 2012: The World of the Neo-Hittite Kingdoms: A Political and Military History. Oxford, Oxford University Press

Castellano, L. 2018: 'Staple economies and storage in post-Hittite Anatolia: considerations in light of new data from Niğde-Kınık Höyük (southern Cappadocia)' Journal of Eastern Mediterranean Archaeology and Heritage Studies 6.4: 259-84. https://doi.org/10.5325/jeasmedarcherstu.6.4.0259

Çevik, Ö. 2007: 'The emergence of different social systems in Early Bronze Age Anatolia: urbanisation versus centralisation’ Anatolian Studies 57: 131-40. https://doi.org/10.1017/s0066154600008553

Charbonnier, J. 2019: 'Human adaptation in Arabia: the role of hydraulic technologies' in E. Chiotis (ed), Climate Changes in the Holocene: Impacts and Human Adaptation. London/New York, Taylor \& Francis: 221-46. https://doi.org/10.1201/9781351260244-11

d'Alfonso, L. 2014: 'The kingdom of Tarhuntassa: a reassessment of its timeline and political significance' in P. Taracha, M. Kapeluś (eds), Proceedings of the Eighth International Congress of Hittitology. Warsaw, Wydawnictwo Agade: 216-35

- 2019: 'War in Anatolia in the post-Hittite period: the Anatolian hieroglyphic inscription of Topada revised' Journal of Cuneiform Studies 71: 133-52. https://doi.org/10.1086/703857

de Meester, T. 1970: Soils of the Great Konya Basin, Turkey. Wageningen, Centre for Agricultural Publishing and Documentation

Der, L., Issavi, J. 2017: 'The urban quandary and the "mega-site” from the Çatalhöyük perspective' Journal of World Prehistory 30.3: 189-206. https://doi.org/10.1007/s10963-017-9103-x

Dercksen, J.G. 2008: 'Observations on land use and agriculture in Kaneš' in C. Michel (ed.), Old Assyrian Studies in Memory of Paul Garelli. Leiden, Nederlands Instituut voor het Nabije Osten: 139-57

Dinçol, A.M., Yakar, Y., Dinçol, B., Taffet, A. 2000: 'The borders of the appanage kingdom of Tarhuntašša: a geographical and archaeological assessment' Anatolica 36: 1-29. https://doi.org/10.2143/ana.26.0.2015493

Düring, B. 2011: The Prehistory of Asia Minor: From Complex Hunter-Gatherers to Early Urban Societies. Cambridge, Cambridge University Press. https://doi.org/10.1017/cbo9780511778926.010 
Düring, B., Glatz, C. (eds) 2015: Kinetic Landscapes: The Cide Archaeological Project: Surveying the Turkish Western Black Sea Region. Berlin, de Gruyter. https://doi.org/10.1515/9783110444971

Dusinberre, E.R.M. 2013: Empire, Authority, and Autonomy in Achaemenid Anatolia. Cambridge, Cambridge University Press

- 2019: 'The collapse of empire at Gordion in the transition from the Achaemenid to the Hellenistic world' Anatolian Studies 69: 109-32. https://doi.org/10.1017/s0066154619000073

Eastwood, W.J., Roberts, N., Lamb, H.F. 1998: 'Palaeoecological and archaeological evidence for human occupance in southwest Turkey: the Beyşehir Occupation Phase' Anatolian Studies 48: 69-86. https://doi.org/10.2307/3643048

Efe, T., Türkteki, M. 2005: 'The stratigraphy and pottery of the period transitional into the Middle Bronze Age at Küllüoba (Seyitgazi-Eskişehir)' Anatolia Antiqua 13: 119-44. https://doi.org/10.3406/anata.2005.1041

Efe, T., Türkteki, M., Fidan, E., Sarı, D., Türkteki, S. 2016: 'Küllüoba kazıları 2014' Kazı Sonuçları Toplantısı 37.2: 233-42

Emre, K. 1964: 'The pottery of the Assyrian Colony period according to the building levels of the Kaniş karum’ Anadolu 7: 87-99

Erbil, Y., Mouton, A. 2018: 'From Ikkuwaniya to Ura: a reassessment of the geography of the Hūlaya River Land according to the Hittite archaeological and philological evidence' Anatolica 44: 75-122

Erdal, Y.S., Erdal, Ö.D. 2012: 'Organized violence in Anatolia: a retrospective research on the injuries from the Neolithic to Early Bronze Age’ International Journal of Paleopathology 2: 78-92. https://doi.org/10.1016/j.ijpp.2012.09.014

Ergürer, H. 2016: Niğde Kinik Höyük Demir Çăgi Seramikleri. PhD thesis, Atatürk University, Erzurum

Fairbairn, A. 2014: 'Preliminary archaeobotanical investigations of plant production, consumption, and trade at Bronze Age Kültepe-Kanesh' in L. Atıcı, F. Kulakoğlu, G. Barjamovic, A. Fairbairn (eds), Current Research at Kültepe/Kanesh: An Interdisciplinary and Integrative Approach to Trade Networks, Internationalism, and Identity. Atlanta, Lockwood Press: 177-94. https://doi.org/10.2307/j.ctvvnd58.14

Forlanini, M. 2017: 'South central: the Lower Land and Tarhuntašša' in M.Weeden, L. Ullmann (eds), Hittite Landscape and Geography. Leiden, Brill: 239-52

French, D.H. 1966: Lists and Maps of Sites in the Konya, Çumra and Karaman Areas. Unpublished pamphlet, British Institute at Ankara, Ankara

Garstang, J. 1944: 'The Hulaya River Land and Dadassas: a crucial problem in Hittite geography' Journal of Near Eastern Studies 3: 14-37. https://doi.org/10.1086/370697

Glatz, C. 2009: 'Empire as network: spheres of material interaction in Late Bronze Age Anatolia' Journal of Anthropological Archaeology 28: 127-41. https://doi.org/10.1016/j.jaa.2008.10.003

Goedegebuure, P., van den Hout, T., Osborne, J., Massa, M., Bachhuber, C., Şahin, F. 2020: ‘TÜRKMEN-KARAHÖYÜK 1: a new Hieroglyphic Luwian inscription from Great King Hartapu, son of Mursili, conqueror of Phrygia' Anatolian Studies 2020: 29-43

Göktürk, O.M. 2011: Climate in the Eastern Mediterranean through the Holocene Inferred from Turkish Stalagmites. PhD thesis, Bern University

Güneri, S. 1987: 'Orta Anadolu höyükleri' Araştırma Sonuçları Toplantısı 4: 207-25

- 1989: 'Orta Anadolu höyükleri: Karaman-Ereğli araştırmaları’ Türk Arkeoloji Dergisi 28: 97-144

- 2013: 'Three flange hilted bronze daggers from Konya Karahöyük' Anatolia Antiqua 21: 23-32. https://doi.org/10.3406/anata.2013.1338

Gurney, O. 1993: ‘The treaty with Ulmi-Tešub' Anatolian Studies 43: 13-28. https://doi.org/10.2307/3642962

Harmanşah, Ö. (ed) 2014: Of Rocks and Water: Towards an Archaeology of Place. Oxford, Oxbow Books

— 2017: 'Borders are rough-hewn: monuments, local landscapes, and the politics of place in a Hittite borderland' in E. Baysal, L. Karakatsanis (eds), Bordered Places, Bounded Times: Cross-Disciplinary Perspectives on Turkey. London, British Institute at Ankara: 27-52. https://www.jstor.org/stable/10.18866/j.ctt1n7qk1h

Harmanşah, Ö., Johnson, P. 2012: 'Yalburt yaylası (Ilgın, Konya) arkeolojik yüzey araştırma projesi, 2010 sezonu sonuçları' Araştırma Sonuçları Toplantısı 29.2: 335-60

Hawkins, J.D. 1995: The Hieroglyphic Inscriptions of the Sacred Pool Complex at Hattuša (SÜDBURG). Weisbaden, Harrassowitz

- 2000: Corpus of Hieroglyphic Luwian Inscriptions 1. Berlin, de Gruyter

Hodder, I. 2014: 'Çatalhöyük: the leopard changes its spots: a summary of recent work' Anatolian Studies 64: 1-22. https://doi.org/10.1017/s0066154614000027

Hoffman, I. 1984: Der Erlass Telipinus. Heidelberg, Carl Winter Universitätsverlag 
Jablonka, P. 2016: 'Beyond the citadel: a map of greater Early Bronze Age Troy' in E. Pernicka, S. Ünlüsoy, S. Blum (eds), Proceedings of the International Conference 'Early Bronze Age Troy: Chronology, Cultural Development and Interregional Contacts', Held at Tübingen on 8th-10th May 2009. Tübingen, Wasmuth: 61-74

Jones, M.A. 2019: Searching for Tarhuntassa: Using GIS Spatial Analysis and Diverse Data-sets to Investigate a Question of Historical Geography in Hittite Southern Anatolia. PhD thesis, University of Birmingham

Kabukçu, C. 2017: 'Woodland vegetation history and human impacts in south-central Anatolia 16,000-6500 cal BP: anthracological results from five prehistoric sites in the Konya plain' Quaternary Science Reviews 176: 85-100. https://doi.org/10.1016/j.quascirev.2017.10.001

Kamış, Y. 2019a: ‘Eminler Höyük 2016 ve 2017 yilları yüzey araştırmaları’ Araştırma Sonuçları Toplantısı 36.3: 50312

— 2019b: 'Eminler Höyük and Karaman plain surveys in 2018' ANMED: News of Archaeology from Anatolia's Mediterranean Areas 17: 97-103

Karabıyıkoğlu, M., Kuzucuoğlu, C. 1998: Late Quaternary Chronology, Environmental Evolution and Climatic Change of the Konya Basin. Ankara, Maden ve Tektik Arama Müdürlüğü

Karauğuz, G., Bahar, H., Kunt, H.İ. 2002: 'Kızıldağ üzerine yeni bazı gözlemler' Türkiye Bilimler Akademisi Arkeoloji Dergisi 5: 7-34. https://doi.org/10.22520/tubaar.2002.0002

Karauğuz, G., Kunt, H.İ. 2004: Eskiçag Kaleleri (Orta Anadolu’nun Güney Kesimi). Konya, Çizgi Kitabevi

Kealhofer, L., Grave, P., Voigt, M.M. 2019: 'Dating Gordion: the timing and tempo of Late Bronze and Early Iron Age political transformation' Radiocarbon 61.2: 495-514. https://doi.org/10.1017/rdc.2018.152

Khatchadourian, L. 2012: 'The Achaemenid provinces in archaeological perspective' in D. Potts (ed), A Companion to the Archaeology of the Ancient Near East. Oxford, Wiley-Blackwell: 963-83. https://doi.org/10.1002/9781444360790.ch51

Koparal, E. 2017: 'Borders make the polis: Klazomenai' in E. Baysal, L. Karakatsanis (eds), Bordered Places, Bounded Times: Cross-Disciplinary Perspectives on Turkey. London, British Institute at Ankara: 97-110. https://www.jstor.org/stable/10.18866/j.ctt1n7qk1h

Koparal, E., Ersoy, Y., Massa, M., Demirciler, V. 2017: 'Sampling the Ionian landscapes: an overview of the archaeological surveys in the Klazomenean and Teian chorai' in S. Steadman, G. McMahon (eds), The Archaeology of Anatolia: Recent Discoveries 2. Cambridge, Cambridge Scholars Publishing: 400-25

Kuzucuoğlu, C., Dörfler, W., Kunesch, S., Goupille, F. 2011: 'Mid- to late-Holocene climate change in central Turkey: the Tecer lake record' Holocene Special Issue 21.1: 173-88. https://doi.org/10.1177/0959683610384163

Lawrence, D., Philip, G., Hunt, H., Snape-Kennedy, L., Wilkinson, T.J. 2016: 'Long term population, city size and climate trends in the Fertile Crescent: a first approximation' PLoS One 11.3: https://doi.org/10.1371/journal.pone.0152563

Lawrence, D., Wilkinson, T.J. 2015: 'Hubs and upstarts: pathways to urbanism in the northern Fertile Crescent' Antiquity 89: 328-44. https://doi.org/10.15184/aqy.2014.44

Legarra Herrero, B. 2016: 'Primary state formation processes on Bronze Age Crete: a social approach to change in early complex societies' Cambridge Archaeological Journal 26.2: 349-67. https://doi.org/10.1017/s0959774315000529

Lloyd, S., Mellaart, J. 1962: Beycesultan 1: The Chalcolithic and Early Bronze Age Levels. London, British Institute of Archaeology at Ankara. https://www.jstor.org/stable/10.18866/j.ctt1pc5gk6

Makowski, M. 2014: 'The road to the citadel of Kanesh: urban structure and spatial organization of the city during the Assyrian Colony period' in P. Bieliński, M. Gawlikowski, R. Koliński, D. Ławecka, A. Sołtysiak, Z. Wygnańska (eds), Proceedings of the Eighth International Congress on the Archaeology of the Ancient Near East. Wiesbaden, Harassowitz: 93-112

Maner, Ç. 2017: 'From the Konya plain to the Bolkar mountains: the 2015-2016 campaigns of the KEYAR survey project' in S. Steadman, G. McMahon (eds), The Archaeology of Anatolia: Recent Discoveries 2. Cambridge, Cambridge Scholars Publishing: 342-67

Manning, S., Griggs, C.B., Lorentzen, B., Barjamovic, G., Bronk Ramsey, C., Kromer, B., Wild, E.M. 2016: 'Integrated tree-ring-radiocarbon high-resolution timeframe to resolve earlier second millennium BCE Mesopotamian chronology' PLoS One 11.7: https://doi.org/10.1371/journal.pone.0157144

Marazzi, M. 2008: 'Messa a coltura e procedure di gestione e controllo dei campi nell'Anatolia hittita: caratteristiche della documentazione e stato della ricerca' in M. Perna, F. Pomponio (eds), The Management of Agricultural Land and the Production of Textiles in the Mycenaean and Near Eastern Economies. Paris, De Boccard: 63-88

Massa, M. 2014: 'Destructions, abandonments, social reorganisation and climatic change in west and central Anatolia at the end of the third millennium BC' in B. Erciyas, E. Sökmen (eds), Regional Studies in Archaeology Symposium Proceedings. Istanbul, Ege Yayınları: 101-23 
- 2016: Networks Before Empires: Cultural Transfers in West and Central Anatolia during the Early Bronze Age. PhD thesis, University College London

Massa, M., Bachhuber, C., Şahin, F., Bostanc1-Kolankaya, N., Tuna, Y. 2019a: 'The Konya Regional Archaeological Survey Project: the 2017 and 2018 field seasons' Anatolica 45: 159-80

Massa, M., Bachhuber, C., Şahin, F., Tuna, Y., Bostanc1-Kolankaya, N. 2019b: 'Konya ili, Karatay ve Çumra ilçeleri arkeolojik yüzey araştırması 2017 yılı’ Araştırma Sonuçları Toplantısı 36.3: 17-34

Massa, M., Palmisano, A. 2018: 'Change and continuity in the long-distance exchange networks between western/central Anatolia, northern Levant and upper Mesopotamia, c. 3200-1600 BC' Journal of Anthropological Archaeology 49: 65-83. https://doi.org/10.1016/j.jaa.2017.12.003

Massa, M., Şahoğlu, V. 2015: 'The 4.2ka climatic event in west and central Anatolia: combining palaeoclimatic proxies and archaeological data' in H. Meller, R. Risch, R. Jung, R.W. Arz (eds), 2200 BC: A Climatic Breakdown as a Cause for the Collapse of the Old World? Halle, Landesmuseums für Vorgeschichte Halle: 61-78

Massa, M., Tuna, Y. 2019: 'A clay stopper from Boz Höyük (Afyon) in the context of the western and central Anatolian Early Bronze Age sealing practices’ Anatolian Studies 69: 59-75. https://doi.org/10.1017/s0066154619000048

Masson, E. 1995: 'La ville Hittite' Semitica 43-44: 63-66

Matessi, A. 2016: 'The making of Hittite imperial landscapes: territoriality and balance of power in south-central Anatolia during the Late Bronze Age' Journal of Ancient Near Eastern History 3.2: 117-62. https://doi.org/10.1515/janeh2017-0004

Matessi, A., Gürel, A., Kuzucuoğlu, C., d'Alfonso, L. 2019: 'East of Konya: settlements, routes and environment in southern Cappadocia, and the political landscape of south central Anatolia during the second millennium BCE' in Ç. Maner (ed), Crossroads: Konya Plain from Prehistory to Byzantine Period: 9th International ANAMED Annual Symposium. Istanbul, Ege Yayınları: 117-46

Matessi, A., Tomassini Pieri, B.M. 2017: 'South-central: archaeology' in M. Weeden, L. Ullmann (eds), Hittite Landscape and Geography. Leiden, Brill: 89-105

Matsumura, K. 2008: 'The Early Iron Age in Kaman-Kalehöyük: the search for its roots' in D. Bonatz, R.M. Czichon, F.J. Kreppner (eds), Fundstellen: gesammelte Schriften zur Archäologie und Geschichte Altvorderasiens ad honorem Hartmut Kühne. Wiesbaden, Harassowitz: 41-50

Melchert, H.C. 2007: 'The borders of Tarhuntassa revisited' in M. Doğan-Alparslan, M. Alparslan, H. Peker (eds), VITA/HAYAT Belkıs Dinçol ve Ali Dinçol'a Armă̆an. Istanbul, Ege Yayınları: 507-14

Mellaart, J. 1955: 'Iron Age pottery from southern Anatolia' Belleten 19.74: 115-37

— 1958: 'Second millennium pottery from the Konya plain and neighbourhood' Belleten 22.87: 311-45

- 1961: 'Early cultures of the south Anatolian plateau, I' Anatolian Studies 11: 159-84. https://doi.org/10.2307/3642460

- 1963: 'Early cultures of the south Anatolian plateau, II: the Late Chalcolithic and Early Bronze Ages in the Konya plain' Anatolian Studies 13: 199-236. https://doi.org/10.2307/3642494

Menze, B., Ur, J. 2012: 'Mapping patterns of long-term settlement in northern Mesopotamia at a large scale' Proceedings of the National Academy of Sciences 109: 778-87. https://doi.org/10.1073/pnas.1115472109

Mielke, D.P. 2011: 'Hittite cities: looking for a concept' in H. Genz, D.P. Mielke (eds), Insights into Hittite History and Archaeology. Leuven, Peeters: 153-94

Omura, S. 2000: 'Preliminary report of the general survey in central Anatolia (1999)' Anatolian Archaeological Studies 9: $37-76$

Orthmann, W. 1963: Die Keramik der frühen Bronzezeit aus Inneranatolien. Berlin, Mann

Osborne, J. forthcoming: The Syro-Anatolian City-States: An Iron Age Culture. Oxford, Oxford University Press

Osborne, J., Massa, M., Şahin, F., Erpehlivan, H., Bachhuber, C. 2020: 'The city of Hartapu: results of the TürkmenKarahöyük Intensive Survey Project' Anatolian Studies 70: 1-27

Otten, H. 1988: Die Bronzetafel aus Boğazköy: ein Staatsvertrag Tuthalijas IV. Wiesbaden, Harrassowitz

Özdoğan, M. 2011: 'The dynamics of cultural change in Anatolia' in Ü. Yalçın (ed), Anatolian Metal 5. Bochum, Deutschen Bergbau-Museum: 21-30

Özgüner, N.P., Summers, G.D. 2017: 'The Çevre Kale fortress and the outer enclosure on the Karacadağ at Yaraşlı' Anatolia Antiqua 25: 1-16

Palmisano, A. 2018: The Geography of Trade: Landscapes of Competition and Long-distance Contacts in Mesopotamia and Anatolia in the Old Assyrian Colony Period. Oxford, Archaeopress. https://doi.org/10.2307/j.ctvndv56t

Roberts, N. 1980: Late Quaternary Geomorphology and Palaeoecology of the Konya Basin (Turkey). PhD thesis, University College London 
Roberts, N., Allcock, S., Arnaud, F., Dean, J.R., Eastwood, W.J., Jones, M.D., Leng, M.J., Metcalfe, S.E., Malet, E., Woodbridge, J., Yiğitbaşığlu, H. 2016: 'A tale of two lakes: a multi-proxy comparison of Lateglacial and Holocene environmental change in Cappadocia, Turkey' Journal of Quaternary Science 31.4: 348-62. https://doi.org/10.1002/jqs.2852

Robinson, D.M. 1927: 'The discovery of a prehistoric site at Sizma' American Journal of Archaeology 31.1: 26-50. https://doi.org/10.2307/497613

Roosevelt, C.H., Luke, C. 2017: 'The story of a forgotten kingdom? Survey archaeology and the historical geography of central western Anatolia in the second millennium BC'European Journal of Archaeology 20.1: 120-47. https://doi.org/10.1017/eaa.2016.2

Rosen, A., Roberts, N. 2006: 'The nature of Çatalhöyük, people and their changing environment on the Konya plain' in I. Hodder (ed), Çatalhöyük Perspectives: Reports from the 1995-99 Seasons. London/Cambridge, British Institute at Ankara/McDonald Institute for Archaeological Research: 41-55

Sagona, A., Zimansky, P. 2009: Ancient Turkey. Abingdon, Routledge

Şahin, F. 2015: 'Küllüoba'da erken Tunç Çağı III döneminde kalınlaştırılmış dudaklı (bead-rim) kaselerin ortaya çıkışı ve gelişimi' Colloquium Anatolicum/Anadolu Sohbetleri 14: 100-19

Schachner, A. 2017: 'The historical development of the urban geography of Hattuša, the Hittite capital city, and beyond' in M. Alparslan (ed), Places and Spaces in Hittite Anatolia 1: Hatti and the East. Istanbul, Türk Eskiçağ Bilimleri Enstitüsü: 29-52

Schoop, U.-D. 2011: 'Hittite pottery: a summary' in H. Genz, D.P. Mielke (eds), Insights into Hittite History and Archaeology. Leuven, Peeters: 241-73

Seeher, J. 2010: 'After the empire: observations on the Early Iron Age in central Anatolia' in I. Singer (ed), ipamati kistamati pari tumatimis: Luwian and Hittite Studies Presented to J. David Hawkins on the Occasion of his 70th Birthday. Tel Aviv, Tel Aviv University: 220-29

Şenyurt, Y., Akçay, A. 2018: 'Topada yazıtına farklı bir bakış: geç Hitit döneminde orta Anadolu' da güç dengeleri' TÜBA-AR 22: 95-117. https://doi.org/10.22520/tubaar.2018.22.006

Şenyurt, Y., Akçay, A., Kara, S. 2019: ‘Alişar-4 seramik geleneği içerisinde Ovaören Demir Çağı geyik figürlü seramikleri' Seleucia 9: 205-45

Şerifoğlu, T.E., Mac Sweeny, N., Stuart, E. 2018: 'Lower Goksu archaeological salvage survey, the fifth season’ Anatolica 44: $165-77$

Singer, I. 1996: Muwatalli's Prayer to the Assembly of Gods through the Storm-God of Lightning (CTH 381). Atlanta, American Schools of Oriental Research

- 2006: 'The failed reforms of Akhenaten and Muwatalli' British Museum Studies in Ancient Egypt and Sudan 6: 37-58

Summers, G.D. 2017: 'After the collapse, continuities and discontinuities in the Early Iron Age of central Anatolia' in A. Schachner (ed), Innovation versus Beharrung: was macht den Unterschied des hethitischen Reichs im Anatolien des 2. Jahrtausends v. Chr? Istanbul, Deutsches Archäologisches Institut: 257-74

Türkeş, M. 1996: 'Spatial and temporal analysis of annual rainfall regimes in Turkey' International Journal of Climatology 16: 1057-76

Umurtak, G., Duru, R. 2014: 'Hacılar büyük höyük kazıları 2013'Arkeoloji ve Sanat 145: 1-20

Ünlüsoy, S., Çilingiroğlu, Ç. 2017: 'Negotiating peace, enduring conflict: a diachronic view on prehistoric warfare in the eastern Aegean' in E. Kozal, M. Akar, Y. Heffron, Ç. Çilingiroğlu, T.E. Şerifoğlu, C. Çakırlar, S. Ünlüsoy, E. Jean (eds), Questions, Dialogues, and Approaches in the Eastern Mediterranean. Münster, Ugarit-Verlag: 97126

Ur, J., Hammer, E. 2009: 'Pastoral nomads of the second and third millennia AD on the Upper Tigris river, Turkey: archaeological evidence from the Hirbemerdon Tepe survey' Journal of Field Archaeology 34: 37-56. https://doi.org/10.1179/009346909791071087

Ur, J., Karsgaard, P., Oates, J. 2007: 'Early urban development in the Near East' Science 317.5842: 1188. https://doi.org/10.1126/science.1138728

van den Hout, T. 1995: Der Ulmitešub-Vertrag: eine prosopographische Untersuchung. Wiesbaden, Harassowitz von der Osten, H. 1937: The Alishar Hüyük: Seasons of 1930-32. Chicago, Chicago University Press

Weeden, M. 2017: 'Tabal and the limits of Assyrian imperialism' in Y. Heffron, A. Stone, M. Worthington (eds), At the Dawn of History: Ancient Near Eastern Studies in Honour of J.N. Postgate. Winona Lake, Eisenbrauns: 721-37

Weingarten, J. 1990: 'The sealing structure of Karahöyük and some administrative links with Phaistos and Crete' Oriens Antiquus 39.1-2: 63-95 
Weiss, H. 2015: 'Megadrought, collapse, and resilience in late 3rd millennium BC Mesopotamia' in H. Meller, R. Risch, R. Jung, R.W. Arz (eds), 2200 BC: A Climatic Breakdown as a Cause for the Collapse of the Old World? Halle, Landesmuseums für Vorgeschichte Halle: $35-52$

Wilkinson, T.J. 2003: Archaeological Landscapes of the Near East. Tucson, University of Arizona

Wilkinson, T.J., Peltenburg, E., Wilkinson, E.B. (eds) 2016: Carchemish in Context: The Land of Carchemish Project 2006-2010. Oxford, Oxbow

Woodbridge, J., Roberts, N., Palmisano, A., Bevan, A., Shennan, S., Fyfe, R., Eastwood, W., Izdebski, A., Çakırlar, C., Woldring, H., Broothaerts, N., Kaniewski, D., Finné, M., Labuhn, I. 2019: 'Pollen-inferred regional vegetation patterns and demographic change in southern Anatolia through the Holocene' The Holocene 29.2: 1-14. https://doi.org/10.1177/0959683619826635

Wossink, A. 2009: Challenging Climate Change: Competition and Cooperation among Pastoralists and Agriculturalists in Northern Mesopotamia (c. 3000-1600 BC). Leiden, Sidestone Press 